\title{
Antimicrobial Peptides as Infection Imaging Agents: Better Than Radiolabeled Antibiotics
}

\author{
Muammad Saeed Akhtar, Muhammad Babar Imran, \\ Muhammad Afzal Nadeem, and Abubaker Shahid \\ Nuclear Medicine Division, Punjab Institute of Nuclear Medicine (PINUM), Faisalabad 38000, Pakistan \\ Correspondence should be addressed to Muammad Saeed Akhtar, saeed_pinum@yahoo.com
}

Received 8 December 2011; Revised 9 February 2012; Accepted 11 March 2012

Academic Editor: Mirian A. F. Hayashi

Copyright (C 2012 Muammad Saeed Akhtar et al. This is an open access article distributed under the Creative Commons Attribution License, which permits unrestricted use, distribution, and reproduction in any medium, provided the original work is properly cited.

\begin{abstract}
Nuclear medicine imaging techniques offer whole body imaging for localization of number and site of infective foci inspite of limitation of spatial resolution. The innate human immune system contains a large member of important elements including antimicrobial peptides to combat any form of infection. However, development of antibiotics against bacteria progressed rapidly and gained popularity over antimicrobial peptides but even powerful antimicrobials failed to reduce morbidity and mortality due to emergence of mutant strains of bacteria resulting in antimicrobial resistance. Differentiation between infection and inflammation using radiolabeled compounds with nuclear medicine techniques has always been a dilemma which is still to be resolved. Starting from nonspecific tracers to specific radiolabeled tracers, the question is still unanswered. Specific radiolabeled tracers included antibiotics and antimicrobial peptides which bind directly to the bacteria for efficient localization with advanced nuclear medicine equipments. However, there are merits and demerits attributed to each. In the current paper, radiolabeled antibiotics and radiolabeled peptides for infection localization have been discussed starting with the background of primitive nonspecific tracers. Radiolabeled antimicrobial peptides have certain merits compared with labeled antibiotics which make them superior agents for localization of infective focus.
\end{abstract}

\section{General Introduction}

Blood-derived antimicrobial proteins and peptides being part of innate immunity target the microbial membranes leading to growth arrest and, in some instants, neutralization of proinflammatory surface components like lipopolysaccharides. Different inflammatory response blood cells like neutrophils, eosinophils, macrophages, and platelets contain antimicrobial proteins and peptides which have affinity for surface lipids of microbial as opposed to eukaryotic cells. Neutrophils contain primary and secondary granules in their cytoplasm which contain antimicrobial proteins and peptides. Lactoferrin is localized in the secondary granules, which has direct microbicidal effect, presumably via membrane disruption. Activated neutrophils release bactericidal/permeability increasing protein (BPI) into inflammatory fluids where it is potentially bactericidal. Serprocidins are proteases with cytotoxic activity localized in neutrophil primary granules.
Cathelicidins are also antimicrobial peptides within secondary granules of neutrophils. The defensins are a family of 4$\mathrm{Kd}$ peptides with broad cytotoxic activity against bacteria, fungi, parasites, viruses, and host cells. Humans express $\alpha$-defensins in neutrophils and $\beta$-defensins in intestinal Paneth cell, as well as pulmonary and reproductive epithelia. The defensins peptides, calprotectin protein, and ubiquicidin cationic peptides are found in macrophages [1]. Platelet $\alpha$ grounds contain certain cationic antimicrobial peptides having broad spectrum antimicrobial activity [2]. Multiple proteins and peptides have been radiolabelled by multiple investigators for specific localization of infection foci but each had certain demerits. More attention diverted to development of new antibiotics followed by radiolabeling but these face the growing problem of microbial resistance.

Differentiation between infection and inflammation is usually difficult. Clinicians use a variety of clues, for example, clinical, laboratory, and radiological tests, to aid in diagnosis 
and influence decision making. Commonly employed and useful modalities for demonstration of any focal lesion include conventional radiological techniques such as X-ray, ultrasound, computerized tomography (CT), magnetic resonance imaging (MRI), which demonstrate structural abnormalities which take some time to become visible, may not always be present, and their resolution lag behind cure. In addition they are neither inflammation nor infection specific. Nuclear medicine has enhanced infection imaging because it depends on the demonstration of pathophysiological and pathological changes, which occur earlier in infection process and also resolve quicker after cure of the infection compared with gross changes in structure [3]. Scintigraphic imaging of inflammation can be achieved in two ways. The first is to utilize the locally enhanced vascular permeability by injecting radiolabelled molecules that show increased extravasation at the site of infection/inflammation. The alternative is to exploit the diapedesis and chemotaxis of leucocytes, either by radiolabelling white blood cells of the patients ex vivo or by directly targeting leukocyte antigens or receptors in vivo via administration of radiolabelled antigranulocyte monoclonal antibodies on receptor-binding ligands [4]. However, nuclear medicine utilizes radiation and must be used as a diagnostic modality in cases where other nonisotopic and noninvasive techniques fail to achieve the target.

Scintigraphy has the advantage of early elucidation of pathophysiological changes in the infective process; however, it is limited by poor resolution. Recent advances in nuclear medicine technology resulted in commercially available instrumentation such as single-photon emission computed tomography (SPECT) and positron emission tomography (PET) that have markedly improved anatomical details. Autologous in vitro ${ }^{111} \mathrm{In}$-oxinate- or ${ }^{99 \mathrm{~m}} \mathrm{Tc}$-HMPAO-labeled leukocytes are still the gold standard for imaging infections [5-7]. Planar images with gamma cameras are handicapped with limited resolution that is not sufficient for assessing the extent of disease. SPECT increases the sensitivity of the nuclear medicine procedures $[8,9]$, but precise anatomical localization of organs is still not possible. Hybrid SPECT/CT improves the diagnostic accuracy when subjected to ${ }^{99 \mathrm{~m}} \mathrm{Tc}$ HMPAO-labeled leukocytes in patients with suspected osteomyelitis [10]. Marked improvement in sensitivity and definition of the extent of infection has been documented with SPECT/CT using ${ }^{67} \mathrm{Ga}-$ and ${ }^{111}$ In-labeled leukocytes [11]. PET/CT with ${ }^{18} \mathrm{~F}$-FDG-labeled autologous leukocytes has further improved the diagnosis and localization of infection lesions [12]; however, the technique is time consuming, demands a sterile environment, and carries the risk of transmission of blood-borne diseases. Antimicrobial compounds that bind to the bacteria would be specific for infection localization if labeled with a suitable isotope because of their selective adhesion to the causative agents [3]. An early antibiotic radiopharmaceutical was ${ }^{99 \mathrm{~m}} \mathrm{Tc}$-ciprofloxacin, which is an analog of a broad-spectrum quinolone antibiotic having the property of binding to DNA gyrase of bacteria and inhibiting DNA synthesis [13]. This ${ }^{99 \mathrm{~m}} \mathrm{Tc}$ agent showed encouraging results in various infections [14-16]; however, specificity was lower than expected, and its accumulation in noninfectious/inflammatory sites has also been reported
[17]. Due to nonspecific accumulation in inflammatory sites, this agent has been proposed for identifying the presence and distribution of inflammation within joints [18]. Bacterial resistance to ciprofloxacin is another disadvantage, which results in false-negative results [19].

Antimicrobial peptides, produced by phagocytes, epithelial cells, endothelial cells, and many other cell types, are an important component of innate immunity against infection by a variety of pathogens [20]. These peptides show antibacterial, antiviral, and antifungal activities in vitro. Bacterial infections with Staphylococcus aureus and Klebsiella pneumoniae have been visualized in mice by ${ }^{99 \mathrm{~m}} \mathrm{Tc}$-labeled human neutrophil peptide-1 [21]. The basis of the antimicrobial activity of these peptides is the interaction of the cationic domains with the negatively charged surface of the microorganisms. The antimicrobial peptide ubiquicidin UBI (2941) (TGRAKRRMQYNRR; 1,693 Da) was originally isolated from mouse macrophage cells. This peptide is identical or highly homologous to $\mathrm{S} 30$, a protein that was purified from the small ribosomal subunit fraction of rat liver and shown to be present in various human and murine tissues [22]. Later, an identical UBI was isolated from human airway epithelial cells. This peptide was labeled with ${ }^{99 \mathrm{~m}} \mathrm{Tc}$, which targeted bacterial cells but not sterile inflammatory processes in experimental animals [23]. In later experiments, it also showed accumulation with high accuracy in fungal infections. This tracer was also used for detection of Staphylococcus aureus infections in mice and Klebsiella pneumoniae in rabbits. As controls, inflammation was produced by lipopolysaccharides (LPSs) and heat-killed microorganisms [24]. Interactions of cationic peptides with bacterial envelopes involve insertion of the peptide into microbial membranes [25] and possibly a sequence-dependent interaction of the antimicrobial peptides with microorganisms [26]. Multiple animal studies using ${ }^{99 \mathrm{~m}}$ Tc-labeled ubiquicidin (29-41) showed encouraging results for differentiation between infection and inflammation model. ${ }^{99 \mathrm{~m}} \mathrm{Tc}-\mathrm{UBI}$ (29-41) scintigraphy showed more accumulation of tracer in Staphylococcusaureus-induced infection compared with that of Escherichia coli infection model. Optimum time for imaging was $60 \mathrm{~min}$ after tracer injection [27]. In another study with this radiolabelled peptide, it was concluded that its accumulation is directly related to viable number of bacteria as tracer accumulation in infective foci declined after administration of ciprofloxacin which reduced the number of bacteria sensitive to this antibiotic. However, serial imaging with ${ }^{99 \mathrm{~m}} \mathrm{Tc}-\mathrm{UBI}$ can be utilized for monitoring efficacy and direction of antibiotic treatment [28]. Use of radiolabeled antimicrobial peptides is only recommended in cases where physician or surgeon is in dilemma to differentiate infection from inflammation. This would avoid blind use of prophylactic antibiotics or as broad spectrum coverage of infection, which results in heavy expenditure and side effects of unnecessary medicines.

Phase-I clinical trial with this novel radiolabelled peptide showed overall sensitivity, specificity, and accuracy of $100 \%$, $80 \%$, and $94.4 \%$, respectively, in patients with soft tissue infections and osteomyelitis. However, optimum time for imaging was $30 \mathrm{~min}$ after intravenous administration of radiotracer [29]. 


\section{Detection of Infection by Nonspecific Tracers}

2.1. Gallium-67-Citrate. The oldest radiopharmaceutical proposed for imaging inflammation is Gallium-67 citrate which has been used for infection and inflammation ever since its discovery in 1971 [30]. ${ }^{67} \mathrm{Ga}$ is a cyclotron-produced radionuclide, with a half-life of 78 hours, emits a broad spectrum of gamma rays between $93 \mathrm{keV}$ and $880 \mathrm{keV}$. The energy peaks that are most suitable for gamma camera imaging are $93 \mathrm{keV}, 184 \mathrm{keV}, 296 \mathrm{keV}$, and $388 \mathrm{keV}$ [31]. After intravenous injection, ${ }^{67} \mathrm{Ga}$ binds to transferrin. This complex extravasates at the site of inflammation due to the locally enhanced vascular permeability, and in the inflammatory lesion it may transchelate to lactoferrin as present in leukocytes. The B-lymphocytes have lactoferrin-binding sites on their surface, which have high affinity for gallium. Additionally, macrophages engulf protein iron complexes and cellular debris, thereby accumulating gallium. Bacteria and fungi contain siderophores which are released for the purpose of scavenging iron and consequently bind gallium as a gallium-siderophore complex [32]. The agent is excreted partly via the kidneys (especially during the first 24 hours after injection) and via the gastrointestinal tract; therefore colon is the target organ. Oral laxatives to reduce bowel activity and to reduce dose to large bowel are not required $[33,34]$. Physiological uptake of the radiolabel also occurs in liver, bone, bone marrow, salivary glands, nasopharynx, and lacrimal glands. For infection or inflammation, imaging can often be accomplished at 48 hours, or even 24 hours, after injection. Planar imaging is performed in the anterior and posterior projection, to include the head, neck, chest, abdomen, pelvis, and proximal extremities. SPECT imaging is performed at 72 hours, which improves the sensitivity and specificity. Most patients exhibit bowel activity at this time; therefore planar and SPECT imaging of abdomen can be performed at 57 days after injection. Inspite of SPECT imaging, there are low spatial resolution and the lack of anatomic landmarks of scintigraphy [35].

Although ${ }^{67} \mathrm{Ga}$-citrate scintigraphy has high sensitivity for both acute and chronic infection and noninfectious inflammation, there are several shortcomings that limit its clinical application. The specificity of the technique is low, due to physiological bowel excretion and accumulation in malignant tissues and areas of bone remodeling. In addition, the radiopharmaceutical has unfavorable imaging characteristics (long physical half-life and high energy gamma radiations), causing high radiation-absorbed doses. Furthermore, optimal imaging often requires delayed recordings up to 72 hours. These unfavorable characteristics, in combination with the development of newer radiopharmaceuticals, have narrowed the clinical indication for gallium scintigraphy to certain conditions such as lung infections and chronic osteomyelitis. The sensitivity and specificity for chronic osteomyelitis are lower than for acute osteomyelitis [36, 37]. Use of SPECT/CT with ${ }^{67} \mathrm{Ga}$ improves diagnostic efficiency as compared with planar or SPECT scanning [11]. Gallium scan is most often used in patients with fever of known origin (FUO), suspected vertebral osteomyelitis, chronic osteomyelitis, pulmonary/mediastinal infections, tuberculosis, sarcoidosis, and retroperitoneal fibrosis. This agent is also valuable for evaluation and followup of drug-induced pulmonary toxic agents like bleomycin and amiodarone. Immunocompromised and neutropenic patients are also candidates for evaluation with gallium scanning [38].

2.2. Nonspecific Immunoglobulins. Initially it was hypothesized that human polyclonal immunoglobulin (HIG) was retained in infectious foci owing to the interaction with $\mathrm{Fc}-\Upsilon$ receptors as expressed on infiltrating leucocytes [39]. Later studies showed that radiolabelled HIG accumulates in infectious foci by nonspecific extravasation due the locally enhanced vascular permeability [40]. For clinical use, HIG has been labeled with ${ }^{111} \mathrm{In}$-oxinate as well as with ${ }^{99 \mathrm{~m}} \mathrm{Tc}$. Both agents have slow blood clearance and physiological uptake in the liver, the spleen, and the kidneys. The ${ }^{99 \mathrm{~m}}$ Tc-labeled preparation has the known ideal radiation characteristics, while the ${ }^{111}$ In-labeled preparation allows imaging at time points beyond 24 hours after injection. ${ }^{111}$ In-oxinate or ${ }^{99 \mathrm{~m}}$ Tc-labeled HIG has been extensively tested in a large number of clinical studies. It has shown excellent performance in the localization of musculoskeletal infection and inflammation [41]. In addition, good results have been reported in pulmonary infection particularly in immunocompromised patients [42] and abdominal inflammation. A general limitation is the long time span between injection and final diagnosis (24-48 hours) [43, 44].

2.3. Liposomes. Liposomes are spheres consisting of one or more lipid bilayers surrounding an aqueous space. They were proposed as vehicles to image infection some 20 years ago, but the preparations used in those early years were cleared from the circulation very rapidly by the mononuclear phagocyte system (MPS). However, if the surface of the liposomes is coated with a hydrophilic polymer such as polyethylene glycol (PEG), they circumvent recognition by the MPS, leading to a prolonged residence time in the circulation and enhanced uptake at pathological sites by extravasation due to locally enhanced vascular permeability [45]. Such stabilized PEG-liposomes can be labeled with ${ }^{111}$ In-oxinate and with ${ }^{99 \mathrm{~m}} \mathrm{Tc}$, either using hexamethylpropylene amine oxime (HMPAO) as an internal label or via HYNIC as an external chelator. Labeling is easy and takes only minutes [46]. The first clinical evaluation showed good imaging of focal infection. In patients suspected of harboring infectious or inflammatory disease, ${ }^{99 \mathrm{~m}} \mathrm{Tc}$-PEG-liposomes were directly compared with ${ }^{111}$ In-IgG scintigraphy. ${ }^{99 m}$ Tc-PEG-liposome scintigraphy has shown high sensitivity (94\%) and specificity (89\%) [47].

2.4. The Avidin-Biotin System. Avidins are a family of proteins present in the eggs of amphibians, reptiles, and birds; streptavidin is a member of the same family. Avidin and streptavidin (mol. wt. 66,000 and 60,000, resp.) bind to biotin with extremely high affinity. Biotin is a compound of low molecular weight that can be radiolabelled. The avidin-biotin approach is based on the fact that avidin (or streptavidin) will nonspecifically localize at sites of infection 
owing to increased vascular permeability. Avidin (or streptavidin) is injected as a pretargeting agent, followed hours later by a second injection with radiolabelled biotin. Good diagnostic accuracy was demonstrated in studies of vascular infection and chronic osteomyelitis [48-51].

\section{Detection of Infection by Specific Tracers}

3.1. Radiolabeled White Blood Cells. Ex vivo labeled autologous leucocytes were developed in the 1970s and 1980s and their use is still considered the "gold standard" nuclear medicine technique for infection and inflammation imaging [5-7]. Although a variety of in vitro leukocyte-labeling techniques have been used, the most commonly used procedure makes use of the lipophilic compounds ${ }^{111}$ In-Oxyquinoline and ${ }^{99 \mathrm{~m}} \mathrm{Tc}-\mathrm{HMPAO}$. The radiolabeling procedure takes about 2-3 hours. Because all the cellular components of the blood can be labeled, it is necessary to separate the leukocytes from the erythrocytes and platelets. After withdrawal, therefore, the syringe containing the blood is kept in the upright position for about 1-2 hour to promote erythrocyte sedimentation. After the erythrocytes have been separated, the leukocytes must be separated from platelets. The leukocyte-rich plasma is centrifuged, and the leukocyte pellet that forms at the bottom of the tube is removed, incubated with the radiolabel, washed, and reinjected into the patient. The usual dose of ${ }^{111}$ In-labeled leukocytes is $10-18.5 \mathrm{MBq}$ (300$500 \mu \mathrm{Ci}$ ); the usual dose of ${ }^{99 \mathrm{~m}} \mathrm{Tc}-\mathrm{HMPAO}$-labeled leukocytes is $185-370 \mathrm{MBq}(5-10 \mathrm{mCi})$. Uptake of labeled leukocytes is dependent on intact chemotoxis, the number and types of cells labeled, and the cellular component of a particular inflammatory response. A total white cell count of at least $2000 / \mathrm{mm}^{3}$ is needed to obtain satisfactory images. Neutrophils can be radiolabeled and hence the procedure is most useful for identifying neutrophil-mediated inflammatory processes, such as bacterial infections. The procedure is less useful for those illnesses in which the predominant cellular response is other than neutrophilic, such as tuberculosis [52].

3.1.1. ${ }^{111}$ In-Oxine-Labeled Leukocytes. For over two decades, ${ }^{111}$ In-oxine-labeled leukocytes have been used to image infection and inflammation. The scintigraphic images reflect the distribution of white blood cells in the body. Since an abscess or other localized infection consists primarily of leukocytes, the radiopharmaceutical localizes at the site of infection [53-61]. After intravenous administration, there is initial sequestration of the labeled leucocytes in the lungs, with subsequent rapid clearance of the activity from the lungs. The radiolabel rapidly clears from the blood and in most cases there is high uptake in granulocytic infiltrates, while a substantial portion of the leucocytes (presumably the damaged cells) accumulate in the spleen. Thus, as a radiopharmaceutical, radiolabelled leucocytes are a specific indicator for leukocytic infiltration, but not for infection $[62,63]$. At 24 hour, after injection, the usual imaging time for ${ }^{111}$ Inlabeled leukocytes, the normal distribution of activity is limited to the liver, spleen, and bone marrow. Large field of view gamma camera equipped with medium energy parallel
TABle 1: Causes of false-negative and false-positive ${ }^{111}$ In leukocyte studies.

\begin{tabular}{l}
\hline False Negative \\
Encapsulated nonpyogenic abscess \\
Vertebral osteomyelitis \\
Chronic low-grade infection \\
Parasitic, mycobacterial or fungal infections \\
Intrahepatic, perihepatic, or splenic infection \\
Hyperglycemia \\
Steroids \\
\hline False Positive \\
Gastrointestinal bleeding \\
Pseudoaneurysm \\
Healing fracture \\
Soft tissue tumor \\
Surgical wounds, stomas, or catheter sites \\
Tumors \\
Accessory spleens
\end{tabular}

hole collimator is used with $15 \%$ window centered on 174 $\mathrm{Kev}$ photopeak and 20\% window centered on the $247-\mathrm{Kev}$ photopeak. Advantages of the ${ }^{111}$ In label are a very stable label and constant normal distribution of activity limited to liver, spleen, and bone marrow. The 67-hour half-life of isotope allows delayed imaging, which is particularly valuable in musculoskeletal infection. Another advantage is conduction of bone or bone marrow scan immediately after completion of ${ }^{111} \mathrm{In}$-labeled study which is a limitation with ${ }^{99 m}$ Tc-labeled tracers [9]. Disadvantages of the ${ }^{111}$ In label include a low photon flux, less than ideal photon energies, and the fact that a 24-hour interval between injection and imaging is generally required. Causes of false-negative and falsepositive ${ }^{111}$ In-leukocyte study are summarized in Table 1 [64]. Drawbacks of ${ }^{111}$ In-labeled white blood cells are laborious and time-consuming preparation, requiring specialized equipment and can be hazardous. Almost 3 hours are required for isolating and labeling a patient's white blood cells by a trained technician. In addition, the need to handle potentially contaminated blood can lead to transmission of blood-borne pathogens such as HIV and HBV. As anatomical land marks are not properly outlined with scintigraphy, the same is the limitation with ${ }^{111} \mathrm{In}-\mathrm{WBC}$ planar images. However, SPECT/CT with ${ }^{111} \mathrm{In}$-WBC scintigraphy markedly improves accurate identification of infection sites [11].

3.1.2. ${ }^{99 \mathrm{~m}}$ Tc-HMPAO-Labeled Leukocytes. The normal biodistribution of ${ }^{99 \mathrm{~m}} \mathrm{Tc}-\mathrm{HMPAO}-\mathrm{labeled}$ leukocytes is more variable. In addition to the reticuloendothelial system, activity is also normally present in the genitourinary tract, large bowel, blood pool, and occasionally the gall bladder [65]. The interval between injection and imaging varies with indication; in general, imaging is usually performed within a few hours after injection. ${ }^{99 \mathrm{~m}} \mathrm{Tc}-\mathrm{HMPAO}$ has theoretical advantages over ${ }^{111} \mathrm{In}$-labeled leukocytes. ${ }^{99 \mathrm{~m}} \mathrm{Tc}$, being generator produced on site, could be immediately available for radiolabeling. The radiation dose to the patient would be 
significantly lower, permitting a higher administered activity. The higher photon yield of ${ }^{99 \mathrm{~m}} \mathrm{Tc}$ would result in superior image resolution and improved infection detectability and accuracy.

HMPAO preferentially labels granulocytes, a potential advantage for imaging acute purulent processes. Unlike ${ }^{111}$ In-oxine-labeled leukocytes, ${ }^{99 \mathrm{~m}} \mathrm{Tc}-\mathrm{HMPAO}-l a b e l e d ~ l e u-$ kocytes are cleared by the hepatobiliary and renal systems [65-70]. Disadvantages include genitourinary tract activity, which appears shortly after injection and colonic activity which appears 4 hours after injection. The instability of the label and the short half-life of ${ }^{99 \mathrm{~m}} \mathrm{Tc}$ are disadvantages when 24-hour imaging is needed. This occurs in those infections that tend to be indolent and for which several hours may be necessary for accumulation of a sufficient quantity of labeled leukocytes to be successfully imaged. Bone or bone marrow scan if indicated after ${ }^{99} \mathrm{~m}$ Tc-HMPAO-WBC scan has to be delayed at least for 48 hours and preferably 72 hours. For better anatomical localization of infection site, SPECT/CT with ${ }^{99 \mathrm{~m}} \mathrm{Tc}-\mathrm{HMPAO}-\mathrm{WBC}$ scintigraphy is far better than planar/SPECT imaging with other infecting imaging agents [10].

3.2. Antigranulocyte Antibodies and Antibody Fragment. Several monoclonal antibodies reactive with antigens expressed on granulocytes (NCA, CD15, CD66, and CD67) have been developed. At least three antigranulocyte antibodies have been tested for infection imaging: anti-NCA-95 IgG (BW250/183) [71, 72], anti-NCA-90 Fab' (Immu-MN3, LeukoScan: anti-CD66) [73], and anti-SSEA-1 IgM (LeuTech: anti-CD15) [74-76]. Each of these antigranulocyte antibodies labeled with ${ }^{99 \mathrm{~m}} \mathrm{Tc}$ or ${ }^{123} \mathrm{I}$ allowed accurate delineation of infection [59]. The antigranulocyte antibody-based radiopharmaceuticals visualized infectious foci in patients with sensitivity between $80 \%$ and $90 \%$ [77].

The use of antibody fragments instead of the whole antibody seems to be more advantageous, since such fragments appear to be less immunogenic. In addition, antibody fragments show faster blood clearance and may thus provide earlier diagnosis. ${ }^{99 \mathrm{~m}} \mathrm{Tc}$-labeled antigranulocyte Fab' fragment (LeukoScan) has been registered in Europe as an infection imaging agent.

3.3. Chemotactic Peptides. A wide variety of peptides that bind to receptors expressed on white blood cells have been tested for the detection of infection. One of the first receptor binding peptide tested for its ability to image infectious foci was chemotactic peptide formyl-Met-Leu-Phe. This tripeptide, which is N-terminally formylated, is a chemotactic factor produced by bacteria which binds to receptors on granulocytes and monocytes with high affinity [78-80]. A drawback of using these biologically potent peptides is a transient but severe reduction in peripheral leukocyte counts. Several antagonists were developed to circumvent this undesirable biological activity of the radiolabelled chemotactic peptide. However, these antagonists had lower uptake in the infectious focus, most likely owing to reduced affinity for the receptor [81].
3.4. Cytokines. The attraction of leukocytes to tissues is essential for inflammation and host response to infection. The process is controlled by chemokines, which are chemotactic cytokines. Over 40 chemokines have been identified to date, most of them in the past few years. Chemokines induce cell migration and activation by binding to specific G-proteincoupled cell surface receptors on target cells. Their receptors are expressed on different types of leukocytes. Some are restricted to certain cells, whereas others are more widely expressed [82]. Labeled cytokines are an interesting class of protein radiopharmaceuticals of low molecular weight $(<20,000)$.

3.5. Interleukin-1. Interleukin-1 (IL-1) binds receptors expressed mainly on granulocytes, monocytes, and lymphocytes, with high affinity. Studies in mice with focal Staphylococcus aureus infections showed specific uptake of radioiodinated IL-1 at the site of infection [83]. Fever, haemodynamic and hematological side effects, occurring even at very low concentrations, are the major drawbacks of the use of such a biologically active protein [84].

3.6. Interleukin-2. The IL-2 is considered to bind specifically to IL-2 receptors expressed on activated T lymphocytes. In a study in an animal model of human autoimmune diabetes mellitus, Hashimoto's thyroiditis, Grave's disease, Crohn's disease, Coeliac disease and other autoimmune diseases, demonstrated localization of ${ }^{123} \mathrm{I}$ or ${ }^{99 \mathrm{~m}} \mathrm{Tc}$-labeled IL-2 at the site of lymphocytic infiltration $[85,86]$.

3.7. Interleukin-8. IL-8 binds to receptors on neutrophils with high affinity. In rabbits with focal Escherichia coli infection, accumulation of ${ }^{123}$ I-labeled IL- 8 in the abscess was rapid and high. The specific activity of this IL-8 preparation was relatively low, resulting in a transient reduction in peripheral leukocyte counts to $45 \%$ after a dose of $25 \mu \mathrm{g} / \mathrm{kg}{ }^{123} \mathrm{I}-\mathrm{IL}-8$, followed by leukocytosis for several hours. Recently, a ${ }^{99 \mathrm{~m}}$ Tc-labelled IL-8 preparation was developed using HYNIC as a chelator. In rabbits with Escherichia coli infection, high abscess uptake of ${ }^{99 \mathrm{~m}} \mathrm{Tc}-\mathrm{HYNIC}-\mathrm{IL}-8$ and high abscess-to-background ratios were obtained compared with those obtained using the radioiodinated preparation [87-91].

3.8. Platelet Factor-4. Platelet factor 4 (PF-4), like IL-8, is a member of the CXC chemokines. PF- 4 binds the CXC type II (= IL-8 type B) receptors expressed on neutrophils and monocytes. In a rabbit model of infection, ${ }^{99 \mathrm{~m}} \mathrm{Tc}-\mathrm{P} 483 \mathrm{H}$ clearly delineated the infectious foci as early as 4 hours after injection. No systemic side effects were observed. ${ }^{99 \mathrm{~m}} \mathrm{Tc}-\mathrm{P} 483 \mathrm{H}$ has been studied in patients to test its applicability as an imaging agent for scintigraphic detection of infection and inflammation, with fair results ( $82 \%$ sensitivity, $77 \%$ specificity) $[92,93]$.

3.9. Detection of Infection by ${ }^{18} F$-Deoxyglucose (FDG). FDG is transported into cells by glucose transporters and is phosphorylated by hexokinase enzyme to ${ }^{18} \mathrm{~F}-2$-FDG- 6 phosphate 
but is not metabolized. The degree of cellular FDG uptake is related to the cellular metabolic rate and the number of glucose transporters [94-96]. Activated inflammatory cells also demonstrate increased expression of glucose transporters. In addition, in inflammatory conditions, the affinity of glucose transporters for deoxyglucose is apparently increased by various cytokines and growth factors, a phenomenon that has not been observed in tumors [97]. Although FDG uptake can produce false-positive results in patients with known or suspected malignancy, FDG represents another potentially useful radiotracer in the setting of infection and inflammation. The areas of normal distribution of FDG include the brain, myocardium, and genitourinary tract. Activity in the bone marrow, stomach, and bowel is variable [98]. Thymic uptake, especially in children, can also be observed [99]. Hepatic and splenic uptake are generally of low grade and diffuse; however intense uptake in spleen may be visualized in the setting of infection [100].

Positron emission tomography (PET) with ${ }^{18} \mathrm{FDG}$ is now widely used. FDG is taken up by inflammatory cells with increased metabolic requirements. In contrast to glucose, deoxyglucose cannot leave the cell once it is taken up, so it can be used to image scintigraphically cells with high glucose uptake such as tumor cells and inflammatory cells. FDG-PET has been studied in a wide variety of infections, including lesions of bacterial, tuberculous, fungal, soft tissue, and bone infections $[101,102]$. Sensitivity and specificity have generally exceeded $90 \%$. This radiotracer has high positive predictive value to localize in infective sites of patients with AIDS and fever of unknown origin (FUO). This technique accurately helps identify sites of infective endocarditis and is promising supplement to conventional echocardiography [103]. FDG-PET has been especially successful in cases of osteomyelitis [104-107]. For vertebral osteomyelitis, high sensitivity, specificity, and accuracy comparable to those of gallium imaging have been reported [108]. High spatial resolution and rapid accumulation in infectious foci are significant advantages over conventional imaging techniques such as the use of labeled leucocytes. However, the fact that uptake occurs in any cell type with high glycolytic activity is a serious limitation of the use of FDG-PET for infection imaging, restricting its specificity [109]. PET is highly sensitive but may be unable to define the anatomic location of a focus of increased ${ }^{18} \mathrm{~F}-\mathrm{FDG}$ accumulation. The hybrid PET/CT technology improved diagnostic accuracy with precise registration of metabolic and structural imaging data. ${ }^{18}$ F-FDG PET/CT utilized for workup of osteomyelitis in diabetic foot correctly identified $93 \%$ of all infected sites [110]. However, ${ }^{18}$ F-FDG-WBC is a nonspecific tracer of increased glucose metabolism and does not accumulate only in sites of infection and inflammation but also shows falsepositive results in tumor and postoperative changes [111]. ${ }^{18}$ F-FDG-labeled autologous leukocytes PET/CT for infection detection has demonstrated sensitivity, specificity, and accuracy of $91 \%, 85 \%$, and $90 \%$, respectively. Negative predictive value of $100 \%$ with this technique is a hallmark. ${ }^{18} \mathrm{~F}-\mathrm{FDG}$-WBC imaging is superior to ${ }^{18} \mathrm{~F}-\mathrm{FDG}$ alone for infection detection as well as for assessment of response of infection to antibiotic treatment; however limited availability and cost are the limitations [12].

\subsection{Detection of Infection by Radiolabeled Antibiotics}

3.10.1. Ciprofloxacin. The first antibiotic developed as a radiopharmaceutical was ${ }^{99 \mathrm{~m}} \mathrm{Tc}$-ciprofloxacin having many of the properties of an ideal infection-specific agent [3]. Ciprofloxacin is a broad spectrum quinolone which binds specifically to bacterial DNA gyrase, inhibits DNA synthesis, and has been proposed to distinguish infection from inflammation $[112,113]$. It is retained at sites of infection and associates freely with metal ions, allowing it to be labeled with technetium. Ciprofloxacin also binds to the equivalent mammalian enzyme, topoisomerase II, but with 100 to 1000 times lesser affinity and the binding is readily reversible. Similarly, it penetrates neutrophils, macrophages, and other cells and tissues, but is not retained for prolonged periods. Thus after the initial distribution phase, as the serum concentration falls, the antibiotic readily leaches out of the cells and tissues into tissue fluid and then the blood and excreted freely, predominantly in the urine. However, it is retained at sites of infection, giving high target to background ratio permitting infection-specific imaging when sequential images are taken at 1, 4 and if required 24 hours after injection [3].

In vitro, ciprofloxacin is taken up by a wide variety of Gram-positive, Gram-negative, and anaerobic bacteria (including ciprofloxacin-resistant bacteria as long as the resistance is not mediated by cell membrane impermeability, which prevents entry of the antibiotic into the bacterial cell) but not by dead bacteria or white cells $[114,115]$. Biodistribution and dosimetry of ${ }^{99 \mathrm{~m}} \mathrm{Tc}$-ciprofloxacin show rapid, predominantly urinary excretion of the tracer, with low-toabsent brain, lung, and bone marrow uptake and low liver uptake and excretion. Highest radiation dose was received by urinary bladder. Imaging conditions were excellent for both thoracic and abdominal regions, even at early time (60 minutes) after injection [116]. In a comparative study in 51 patients, it demonstrated greater specificity (96\%) for imaging infection compared with white cell imaging (84\%) [113]. High specificity for bacterial infection was confirmed in a subsequent study involving 90 patients [117]. It also showed that some infections due to ciprofloxacin-resistant bacteria could be imaged and that prior antibiotic treatment did not significantly affect the imaging result. The sensitivity and specificity of ciprofloxacin imaging have been validated further in a large multicentre study involving 879 patients, with a wide variety of infective and noninfective conditions (including noninfective inflammatory disorders), in eight countries, under the auspices of the International Atomic Energy Agency (IAEA) [118]. No adverse reactions occurred and antibiotic-resistant organisms did not emerge as a result of the administration of antibiotic into patients. This was expected because only a tracer dose of ciprofloxacin is present in the kit, $2 \mathrm{mg}$, which is $1 / 200$ th of a single therapeutic intravenous dose of ciprofloxacin $(400 \mathrm{mg})$. Sensitivity $(85.4 \%)$ and specificity $(81.7 \%)$ for imaging sites of infection were good, but varied according to the type of 
infections imaged. The highest sensitivity (in excess of 90\%) was seen in osteomyelitis, septic arthritis, infection of orthopedic prostheses (which is often difficult to diagnose by standard techniques and differentiate from aseptic loosening), and culture-proven soft tissue and abdominal infections and tuberculosis. Ciprofloxacin has several advantages over established, for example, radiolabeled leucocytes, and other methods for imaging infection, which include the following: (1) specificity for infection, (2) lack of bone marrow uptake, which is a significant advantage in imaging bone and joint and orthopedic prostheses infections, (3) ease and cost of preparation of the agent, (4) ex vivo labeling, which avoids contact with blood and hence the risk of acquiring bloodborne infections such as H1V and hepatitis B and C, (5) independence of the host inflammatory response and neutrophil count and hence it can be used to image infections in immunocompromised patients, including those who are neutropaenic, where culture is often negative and white cell imaging unreliable, and (6) availability in a kit format with long shelf-life, making it user friendly and more widely available [3]. Certain studies have revealed false positive uptake of ${ }^{99 \mathrm{~m}} \mathrm{Tc}$-ciprofloxacin in sterile inflammation questioning its specificity [14-19].

3.10.2. ${ }^{99 \mathrm{~m}} \mathrm{Tc}$ Sparfloxacin. Sparfloxacin is fluoroquinolon, antibiotic effective against a wide range of Gram-positive bacteria. It was successfully labeled and evaluated in invitro animal model in which ${ }^{99}$ Tc-labeled antibiotic accumulated in infective sites of live Staphylococcus aureus bacteria and revealed no uptake in control models with heat-killed bacteria [119].

3.10.3. ${ }^{99 \mathrm{~m}} \mathrm{Tc}$-Enroflaxacin. This is also quinolone antibiotic used mainly in veterinary practice. Labeled with ${ }^{99 \mathrm{~m}} \mathrm{Tc}$, in vitro studies did not show encouraging results in differentiating infection from inflammatory foci [120].

3.10.4. ${ }^{99 \mathrm{~m}} \mathrm{Tc}$-Ceftizoxime. Ceftizoxime is a $3 \mathrm{rd}$-generation cephalosporin effective against a wide range of Gram-positive bacteria especially Staphylococcus aureus, Streptococci, and Enterobacteriaceae. This drug is widely used at surgical and medical floors as prophylactic and treatment antibiotic. As per hypothesis, if such drugs are effectively labeled with radiotracer without altering the efficacy and effective binding with bacteria, localization of infective foci and monitoring the efficacy and duration of antibiotic treatment would be a big hallmark. This drug was effectively labeled with ${ }^{99 \mathrm{~m}} \mathrm{Tc}$ and used to localize bone infections as the penetration of this antibiotic in bone is far better as compared with other antibiotics [121].

3.10.5. ${ }^{99 \mathrm{~m}} \mathrm{Tc}$-Ethambutol. Ethambutol is a narrow-spectrum antibiotic, which is active against mycobacteria (inhibits cell wall mycolic acid synthesis) and is used as a first-line drug for the treatment of tuberculosis (TB). Hence radiolabeled ethambutol is an attractive candidate for specifically imaging mycobacterial infections, including early TB. Good results were obtained in a thigh model of Mycobacterium tuberculosis infection in mice and rabbits. ${ }^{99 \mathrm{~m}} \mathrm{Tc}$-ethambutol accumulated at the site of infection as early as 2 hours after injection, which increased at 4 hours and persisted till 24 hours. Further studies with this agent are eagerly awaited [122].

3.10.6. ${ }^{99 \mathrm{~m}} \mathrm{Tc}-\mathrm{INH}$. Isoniazid (INH) is a specific antituberculous drug showing selective uptake in live mycobacteria based on its specific interaction with mycolic acid which is an important constituent of bacterial cell wall. This drug was successfully labeled with ${ }^{99 \mathrm{~m}} \mathrm{Tc}$ followed by studies on mice and rabbits for labeling efficiency, in vitro and in vivo stability, blood kinetics, and organ distribution. Thigh model of localized tubercular lesion was prepared in rabbits after injecting $500 \mu \mathrm{L}$ of $3 \times 10^{8}$ cells/mL of Mycobacterium tuberculosis live bacteria in growing phase (clinical human isolate). The localization of radiolabeled complex was studied with $70-75 \mathrm{MBq}$ of ${ }^{99 \mathrm{~m}} \mathrm{Tc}-\mathrm{INH}$ intravenously with successful imaging at 2, 4, and 24 hours after tracer injection with increase in target to nontarget (T/NT) ratio gradually up to 24 hours. Labeling efficiency of the kit was $>95 \%$ and only $2-$ $3.5 \%$ of tracer leaked out from the complex or 24 hours when incubated in serum as $37^{\circ} \mathrm{C}$, confirming its stability. Organ distribution studies showed renal source of excretion with no gastric or thyroid uptake suggesting good in vitro labeling efficiency and stability. As controls, infection was induced in rabbits with live Staphylococcus aureus after injection of $10^{7}$ live bacteria followed by injection of same dose of ${ }^{99 \mathrm{~m}} \mathrm{Tc}$ INH and imaging under same parameters. Tracer accumulation was visualized in the infective foci from 2 hours after injection; however, delayed imaging revealed gradual clearance at 4 and 24 hours, which was in contradiction to findings with tuberculous lesions. Overall more than 95\% sensitivity and high specificity were observed in the animal study. Therefore it was concluded that this radiolabeled agent can be used for detection and followup of tuberculous lesions in patients especially to determine the treatment endpoint of antituberculous drugs [123]. Similar labeling of INH with ${ }^{99 \mathrm{~m}} \mathrm{Tc}$ and study in humans was tried in our set up but we were unable to localize lesions of tuberculous lymphadenitis in humans with this radiotracer.

3.10.7. ${ }^{99 \mathrm{~m}} \mathrm{Tc}$-Fluconazole. Anticancer therapy, transplantation and AIDS give rise to infections with fungi such as Candida albicans and Aspergillus Fumigatus. Fluconazole is antifungal drug which was successfully labeled with ${ }^{99 \mathrm{~m}} \mathrm{Tc}$. This labeled compound successfully detected infections with Candida albicans but not bacterial infections or sterile inflammatory sites in animals. There was good correlation between ${ }^{99 \mathrm{~m}}$ Tc-Fluconazole accumulation and the number of viable Candida albicans which could be used as parameter for monitoring antifungal therapy. This agent is mainly excreted via the kidneys with little accumulation in the liver. However, it is not suited to detect Aspergillus fumigatus infections. However, this radiotracer is able to distinguish between Candida albicans infections from bacterial infections and sterile inflammations [124]. 
3.11. Detection of Infection by Antimicrobial Peptides. Peptides are composed of relatively small components, the amino acids. A difference between peptides and proteins is their size. Peptides are compounds with up to about 50 amino acids and a molecular mass below about 10,000 Dalton. In contrast, they generally do not possess a well-defined threedimensional (tertiary) structure. Because of the lack of tertiary structure, small peptides are less susceptible to a loss of integrity through labeling conditions and are less immunogenic than proteins $[125,126]$. Antimicrobial peptides, produced by phagocytes, epithelial cells, endothelial cells, and many other cell types, are an important component of innate immunity against infection by a variety of pathogens. They can be expressed constitutively or induced during inflammation or microbial challenge. These peptides, which now number more than 100 , with proven microbicidal activity against a variety of microorganisms, share certain properties such as their small size and cationic charge. The later allows them to bind preferentially to a broad spectrum of microorganisms. Interestingly, the antibacterial effect of antimicrobial peptides in experimentally infected animals might also be attributed to synergistic effects with endogenous antimicrobial peptides and proteins such as lysozyme and secretary leukoprotease inhibitor (SLPI), reactive oxygen intermediates, or other local factors (such as $\mathrm{pH}, \mathrm{Ca}^{+2}$ and $\mathrm{Zn}^{+2}$ concentrations) or to interactions with host cells, leading to enhanced antibacterial activities of the cells [127-129].

\section{Key Features of Antimicrobial Peptides}

(i) Antimicrobial peptides usually contain $<50$ amino acids with a net positive charge created by an excess of basic residues, such as lysine and arginine, and 50\% hydrophobic amino acids.

(ii) Antimicrobial peptides are essential components of the innate host defense because of their ability to kill a wide range of pathogens.

(iii) They have a wide distribution throughout the animal and plant kingdoms.

(iv) They are effectors of local and systemic immune responses. The latter is essentially found in insects.

(v) Although they share basic features such as small size, hydrophobicity, and cationic character, antimicrobial peptides have a great structural diversity.

(vi) The majority of antimicrobial peptides are derived from larger precursors that harbor a signal sequence, whereas other peptides are generated by proteolysis from larger proteins (such as lactoferrin).

(vii) In addition, some antimicrobial peptides such as mammalian defensins have other activities contributing to host defenses by mediating an acute inflammatory reaction and linking the innate with the acquired immune response [130].

4.1. Preparation of Radiolabeled Peptides. Difficulties arising in purifying natural antimicrobial peptides from various sources have prompted the recombinant production of
TABLE 2: Natural and synthetic human antimicrobial peptides.

\begin{tabular}{llcc}
\hline Peptide & $\begin{array}{l}\text { Amino } \\
\text { acids }\end{array}$ & Amino acid sequence & Code \\
\hline $1-59$ & [20] & UBI 1-59 \\
$1-18$ & KVHGSLARAGKVRGQTPK & UBI 1-18 \\
& $29-41$ & TGRAKRRMQYNRR & UBI 29-41 \\
Ubiquicidin & $18-29$ & KVAKQEKKKKKT & UBI 18-29 \\
& $18-35$ & KVAKQEKKKKKTGRAKRR & UBI 18-35 \\
& $31-38$ & RAKRRMQY & UBI 31-38 \\
& $22-35$ & QEKKKKKTGRAKRR & UBI 22-35 \\
& $1-692$ & [27] & hLF \\
$1-11$ & GRRRRSVWCA & hLF 1-11 \\
& $2-11$ & RRRRSVQWCA & hLF 2-11 \\
3-11 & RRRSVQWCA & hLF 3-11 \\
Lactoferrin & RRSVQWCA & hLF 4-11 \\
& $5-11$ & RSVQWCA & hLF 5-11 \\
& $6-11$ & SVQWCA & hLF 6-11 \\
$21-31$ & FQWQRNMRKVR & hLF 21-30 \\
\hline Defensin 1-3 $1-30$ & [28] & -
\end{tabular}

antimicrobial peptides by genetically engineered bacteria or by peptide synthesis. Such methods result in sufficient amounts of antimicrobial peptides produced under good laboratory practice conditions, which is essential for use in animal and human studies. Synthetic peptides are usually small, rapidly removed from the circulation and other body compartments, and flexible, because they do not hold a particular structure in a hydrophilic environment, and display a favorable adverse effect profile.

4.2. Radiolabeling of Peptides. The aim of radiolabeling techniques is to firmly attach or incorporate the radionuclide into the peptide without altering its biological functions, thus allowing a reliable evaluation of its pharmacokinetics after intravenous administration. The various methods of labeling peptides with ${ }^{99 \mathrm{~m}} \mathrm{Tc}$ including indirect labeling using the preformed chelate approach or bifunctional chelating agents and the direct labeling method have been discussed extensively [131]. The direct labeling method is a simple procedure in which the peptide is labeled in absence of an exogenous chelator. The labeling of antimicrobial peptides is rapid (within $10 \mathrm{~min}$ ), effective (impurities, $5 \%$ of the total radioactivity), stable (minimal release of radioactivity from the ${ }^{99 \mathrm{~m}} \mathrm{Tc}$-peptide in diluted human serum), and safe (no adverse effects in mice and rabbits). Unfortunately, the reaction mechanism underlying this ${ }^{99} \mathrm{~m}$ Tc-labeling of peptides has not been elucidated. It may, however, involve the reduction of ${ }^{99 \mathrm{~m}} \mathrm{Tc}$, the production of a ${ }^{99 \mathrm{~m}} \mathrm{Tc}$ intermediate, and the substitution reaction transferring the reduced ${ }^{99 \mathrm{~m}} \mathrm{Tc}$ from this intermediate to the peptide [132].

4.3. Selection of ${ }^{99 \mathrm{~m}} T \mathrm{~T}$-Labeled Antimicrobial Peptides for Scintigraphic Studies. In vitro binding studies were used to select peptides displaying a preferential binding to microorganisms over human cells from a range of ${ }^{99 \mathrm{~m}} \mathrm{Tc}$-labeled 


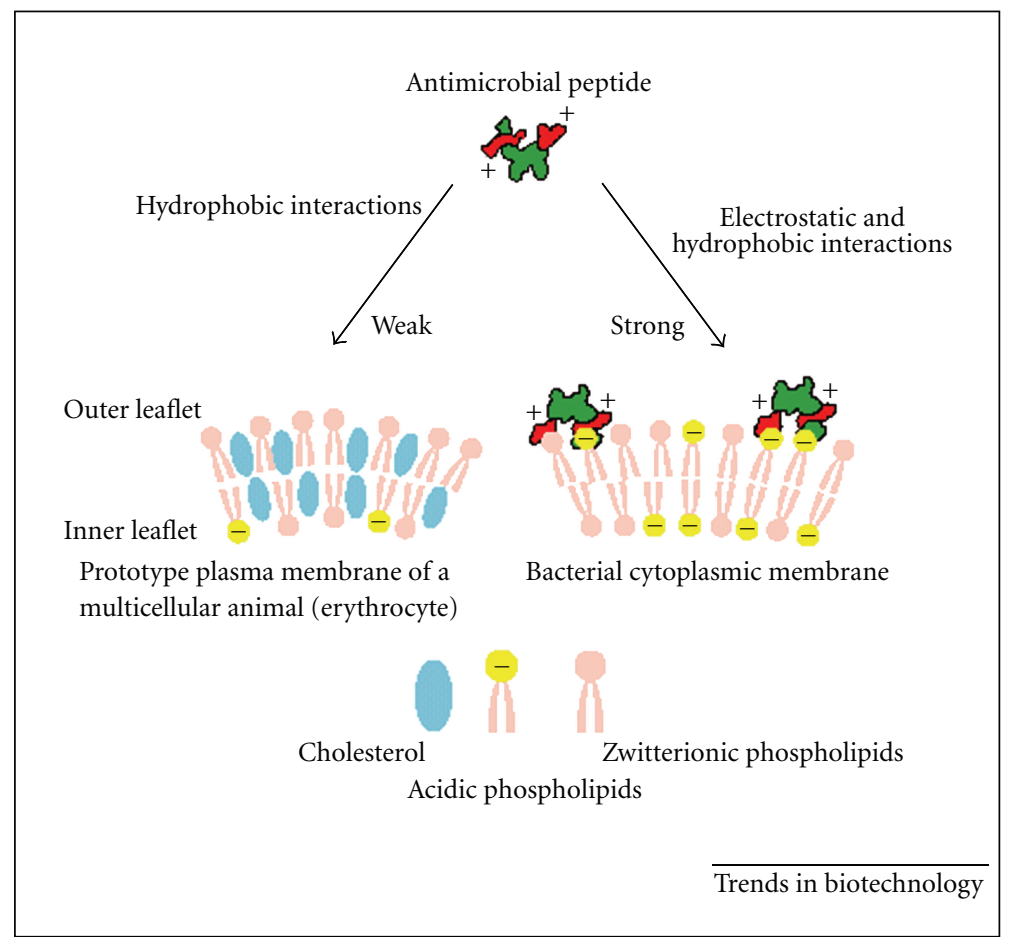

FIGURE 1: The membrane target of antimicrobial peptides and the basis of their specific binding.

human antimicrobial peptides/proteins and synthetic peptides derived from these natural peptides/proteins (Table 2). Thereafter, a peritoneal infection model was used to assess the in vivo binding of ${ }^{99 \mathrm{~m}} \mathrm{Tc}$-peptides to bacteria and host cells. Next, radiolabeled peptides that had been selected by this assay were injected into animals to find out whether they can be used to discriminate infections from sterile inflammatory lesions using scintigraphic techniques. Peptides were also selected on the basis of favorable pharmacokinetics. After these phases of selection, $\alpha$-defensins and several peptides derived from ubiquicidin were seen to be the most likely candidates for infection detection [133].

4.4. Mechanism of Labeled Peptides for Infection Detection. Although antimicrobial peptides have different chemical structures, the basis of their antimicrobial activities is the interaction of the cationic (positively charged) domains of the peptides with the (negatively charged) surface of microorganisms (Figure 1). Given that microbial membranes expose negatively charged phospholipids, such as LPS or teichoic acids, on their surface, whereas mammalian cells segregate lipids with negatively charged head groups into the inner leaflet, it is conceivable that antimicrobial peptides bind preferentially to pathogens over mammalian cells [130].

4.5. Antimicrobial Peptides in Experimental Use. One of the best-studied antimicrobial peptides is human neutrophil peptide-1 (HNP-1), which is a member of the family defensins. Initially, the potential use of HNP-1 for antibacterial therapy of experimental infections in mice was studied. The antibacterial effect was found to be associated with an increased influx of neutrophils into the infected area [134]. Use of this agent in experimental thigh muscle infection in mice allowed rapid visualization of bacterial infections, but abscess to background ratios were low and decreased with time $[135,136]$.

4.6. Imaging of Infections in Immunocompromised Mice. Immunocompromised mice produced by an injection of cyclophosphamide were utilized for detection of infection site induced by microorganisms which confirmed that accumulation of tracer was due to microorganisms, not due to inflammatory cells [24]. In immunocompromised animals the accumulation of the peptide at the infection site was similar to that in immunocompetent rabbits, thus confirming insignificant contribution of the labeling with activated leukocytes and other inflammatory cells $[27,28]$.

4.7. Discrimination between Infection and Inflammation. Antimicrobial peptides labeled with ${ }^{99 \mathrm{~m}} \mathrm{Tc}$ selectively localized the infection sites of bacteria and fungi through binding with their cell membranes and revealed minimum or no uptake in inflammatory model induced by LPS or heat-killed microorganisms [24]. Similarly, no binding of labeled ${ }^{99 \mathrm{~m}} \mathrm{Tc}-\mathrm{an}-$ timicrobial peptide UBI (29-41) was appreciated in inflammatory models in rabbits induced with formalin-killed Staphylococcus aureus bacteria or turpentine oil [27].

4.8. Ubiquicidin (UBI 29-41): New Antimicrobial Peptide. UBI (29-41) (TGRAKRRMQYNRR, 1,693 Da) was originally 
<smiles>CSCCC(NC(=O)C(CCCNC(=N)N)NC(=O)C(CCCNC(=N)N)NC(=O)C(CCCCN)NC(=O)C(C)NC(=O)C(CCCNC(=N)N)NC(=O)CNC(=O)C(N)C(C)O)C(=O)NC(CCC(=O)O)C(=O)NC(Cc1ccc(O)cc1)C(=O)NC(CC(N)=O)C(=O)NC(CCCNC(=N)N)C(=O)NC(CCCNC(=N)N)C(=O)O</smiles>

Figure 2: Structure of UBI 29-41.

isolated from the cytosolic fraction of IFN- $\gamma$-activated cells of mouse macrophage cell line RAW264.7 (Figure 2). Later, an identical UBI was isolated from human H292 airway epithelial cells. Ubiquicidin is identical or highly homologous to $\mathrm{S} 30$, a protein that was purified from the small ribosomal subunit fraction of rat liver and shown to be present in various human and murine tissues. The homology of the precursor element of this protein to ubiquitin and the fact that it is probably widely expressed named this protein ubiquicidin (Latin "ubique," everywhere) [137].

4.8.1. Radiochemical Analysis. HPLC chromatograms for UBI peptides indicated that the preparations were more than $95 \%$ pure. ITLC analysis of the preparation containing radiolabeled peptide showed peptide-labeling yield of $98 \%$ after 10 minutes of incubation and these values remained unchanged up to 24 hours [20].

4.8.2. Stability of ${ }^{99 \mathrm{~m}}$ Tc-Labeled UBI in Human Serum. Stability of the ${ }^{99 \mathrm{~m}}$ Tc-labeled UBI peptides was assessed by incubating one volume of the labeling solution with one volume of $20 \%(\mathrm{v} / \mathrm{v})$ human serum in saline for 1 and 24 hours at $37^{\circ} \mathrm{C}$. Next, the amounts of free pertechnetate and ${ }^{99 \mathrm{~m}}$ Tc-peptide in the samples were determined by ITLC using methyl ethyl ketone as eluent. Results showed minimal release of radioactivity from the ${ }^{99 \mathrm{~m}} \mathrm{Tc}$-UBI peptides. ITLC analysis of the samples after 1 and 24 hours of incubation in human serum revealed small amounts of released/free ${ }^{99 \mathrm{~m}} \mathrm{Tc}$ ( $<3 \%$ of the total activity at both intervals) [138].

4.8.3. Binding of UBI to Bacteria and Murine Blood Cells. Analysis of murine blood revealed that only a small proportion of the intravenously injected ${ }^{99 \mathrm{~m}} \mathrm{TC}-\mathrm{UBI}$ is associated with blood cells. Moreover, injection of excess unlabeled UBI 29-41 into Staphylococcus-aureus-infected mice prior to injection of ${ }^{99 \mathrm{~m}}$ Tc UBI $29-41$ significantly $(P<0.05)$ reduced the accumulation of this radiopharmaceutical at the site of infection. In addition, significantly $(P<0.01)$ higher amounts of ${ }^{99 \mathrm{~m}} \mathrm{Tc}$-UBI $29-41$ accumulated at the site of infection in mice using a carrier-free radiolabeled UBI 29-41 as compared with unpurified preparation containing radiolabeled UBI 29-41 [20].
4.8.4. In Vitro Binding of UBI and Two Other Cationic Peptides to Bacteria and Tumor Cell Lines. A comparative study of the in vitro binding of ${ }^{99 \mathrm{~m}} \mathrm{Tc}$-UBI and two different ${ }^{99 \mathrm{~m}}$ Tc-labeled cationic peptides $\left({ }^{99 \mathrm{~m}} \mathrm{Tc}\right.$-Tat-1-Scr and ${ }^{99 \mathrm{~m}} \mathrm{Tc}$-Tat-2-Scr) to bacteria and to two tumor cell lines (LS174T and ACHN) was performed. The binding of ${ }^{99 \mathrm{~m}} \mathrm{Tc}-\mathrm{UBI},{ }^{99 \mathrm{~m}} \mathrm{Tc}-\mathrm{Tat}-1-\mathrm{Scr}$, and ${ }^{99 \mathrm{~m}} \mathrm{Tc}$-Tat-2-Scr to Staphylococcus aureus was $35 \%, 78 \%$, and $87 \%$, respectively. While the binding of ${ }^{99 \mathrm{~m}} \mathrm{Tc}-\mathrm{Tat}-1-\mathrm{Scr}$ and ${ }^{99 \mathrm{~m}} \mathrm{Tc}$-Tat-2-Scr was $37 \%$ and $33 \%$ to colon tumor cells (LS174T) and 39\% and 41\% to renal tumor cells (ACHN), respectively. Binding of ${ }^{99 \mathrm{~m}} \mathrm{Tc}$-UBI to both cell types was much lower $(<4 \%)$ [138].

4.8.5. In Vivo Binding Studies. Experimental peritoneal infection in mice showed highest binding of ${ }^{99 \mathrm{~m}} \mathrm{Tc}$-labeled UBI peptides to bacteria. The mean ratio between binding of UBI peptides to bacteria and that to leukocytes, determined at 2 and 24 hours, amounted to $73-220$ [20]. The in vivo specificity of ${ }^{99 \mathrm{~m}} \mathrm{Tc}$-UBI for infection in mice was also evaluated using dual labels in the same animal and comparing the target/nontarget ratio for ${ }^{67} \mathrm{Ga}$-citrate and ${ }^{99} \mathrm{~m} \mathrm{Tc}-\mathrm{UBI}$ at sites of induced infection and sterile inflammation. This study revealed that there is a significant difference $(P<0.05)$ in the radioactive accumulation of ${ }^{99 \mathrm{~m}} \mathrm{Tc}$-UBI between the sites of infection and inflammation compared to ${ }^{67} \mathrm{Ga}$-citrate. Thus, ${ }^{99 \mathrm{~m}} \mathrm{Tc}$-UBI showed an average infection/inflammation ratio of $2.08 \pm 0.49$ compared to $1.14 \pm 0.45$ for ${ }^{67} \mathrm{Ga}$-citrate. In conclusion, the in vitro and in vivo results provide evidence that a specific mechanism is responsible for the ${ }^{99 \mathrm{~m}} \mathrm{Tc}-\mathrm{UBI}$ bacterial intracellular accumulation [138].

4.8.6. Infection Imaging in Animal Models. In experimental animals, various ${ }^{99 \mathrm{~m}} \mathrm{Tc}$-labeled UBI peptides visualized the bacterial or fungal infected tissues within 30 minutes after injection. A good correlation between the accumulations of ${ }^{99 \mathrm{~m}}$ Tc-labeled UBI peptides in Staphylococcus-aureus-infected thigh muscles in mice and the number of viable bacteria present at the site of infection was recorded. In immunocompromised animals the accumulation of the peptide at the site of infection seemed to be similar to that in immunocompetent mice, confirming the insignificant contribution 


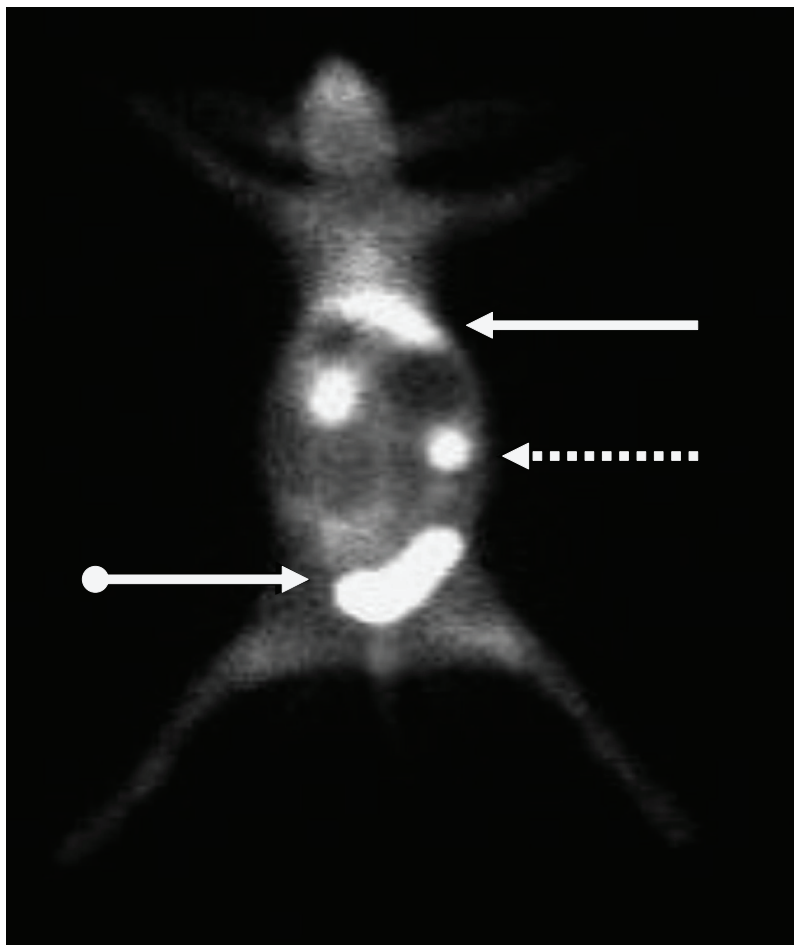

FIgURE 3: Biodistribution of ${ }^{99 m}$ Tc UBI $29-41$ in a normal rabbit at 30 minutes after injection.

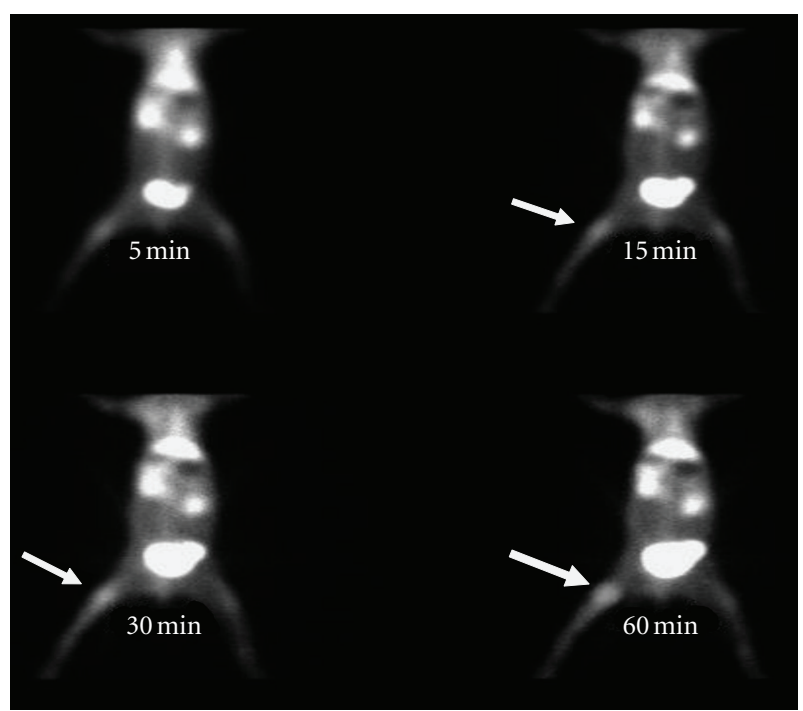

Figure 4: ${ }^{99 \mathrm{~m}}$ Tc-UBI (29-41) scintigram of rabbit with Staphylococcus aureus thigh muscle infection (arrow). Maximum tracer uptake visualized at 60 minutes after tracer injection.

of the direct binding of the tracer to infiltrating leucocytes [133].

4.8.7. Discrimination between Bacterial Infection and Sterile Inflammation. Various experimental thigh muscle infections in mice and rabbits with both Gram-positive and Gram-negative bacteria revealed accumulation of ${ }^{99} \mathrm{~m} \mathrm{Tc}$-labeled UBI at the site of infection within 15-30 minutes after injection. No significant accumulation of labeled peptide was observed in thighs of rabbits and mice previously injected with LPS or heat-killed bacteria (i.e., sterile inflammation) [133]. Only one animal model study provided results against its binding to bacteria and concluded its affinity for ${ }^{3} \mathrm{H}$-deoxyglucose and macrophage accumulation at the site of infection [139].

4.8.8. Biodistribution of UBI in Mice and Rabbits. After injection, ${ }^{99 \mathrm{~m}}$ Tc-labeled UBI peptides are rapidly removed from the circulation via the kidneys. Scintigraphic analysis revealed that, within the first hour after injection of tracer, major part of activity was found in kidneys and urinary bladder with little accumulation in liver, lungs, and spleen (Figure 3) [20, 27, 133].

4.8.9. Infection Detection with ${ }^{99 \mathrm{~m}}$ Tc UBI 29-41 in Animal Model. ${ }^{99 \mathrm{~m}}$ Tc UBI was evaluated as bacterial infection seeking agent in Staphylococcus aureus and Escherichia coli infections in rabbit model. It was concluded that the agent can detect both bacterial infections from sterile inflammatory sites and showed more tracer accumulation in Staphylococcus aureus infections compared with Escherichia coli infections. Optimum time for imaging was 60 minutes after tracer injection (Figure 4) [20]. This peptide also permitted early specific detection of experimental Staphylococcus aureus prosthetic joint infections in animal model and resulted in early detection of acute prosthetic joint infection and differentiated well from chronic sterile prosthetic joint inflammation [140]. Endocarditis is another difficult diagnostic question from cardiologist. In an animal study radiolabeled UBI 


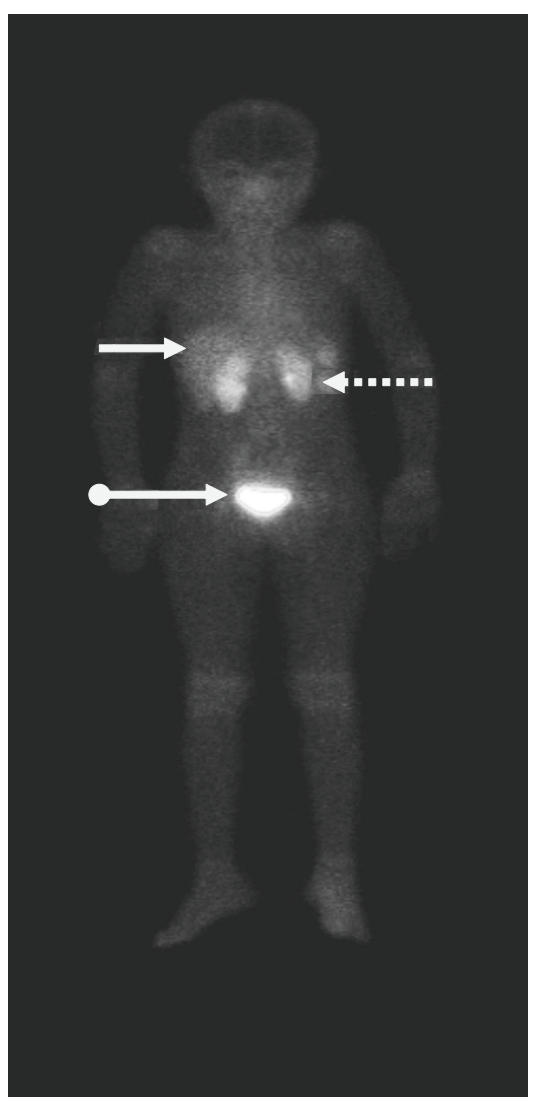

FIGURE 5: Anterior whole body image at 30 minutes after ${ }^{99 \mathrm{~m}} \mathrm{Tc}-\mathrm{UBI}$ 29-41 injection in normal human subject showing kidneys (dotted arrows), liver (solid arrows), and urinary bladder (ball arrow).

29-41 scintigraphy revealed early and specific detection of multidrug-resistant Staphylococcus-aureus-induced endocarditis. Furthermore it was concluded that accumulation of tracer depends on the number of viable bacteria in the vegetation and declared it as dedicated noninvasive imaging tool for early detection of infective endocarditis [141].

\subsubsection{0. ${ }^{99 \mathrm{~m}}$ Tc UBI Scan for Detection of Fungal Infections in} Animals. ${ }^{99 \mathrm{~m}} \mathrm{Tc}$ UBI imaging was also studied in animal models for localization of infection induced with Candida albicans. It was observed that this antimicrobial peptide showed significant accumulation at the site of infection compared with sterile inflammation [142]. This peptide showed binding with Candida albicans and Aspergillus fumigatus in addition to viable bacteria. Therefore this agent is useful for detection of fungal infections; however differentiation would be difficult from bacterial infections. However ${ }^{99 \mathrm{~m}} \mathrm{Tc}-$ fluconazole can be used later on, which binds only with $\mathrm{Ca}$ ndida albicans, shows no binding to bacteria and no accumulation at site of sterile inflammation [143].

4.8.11. ${ }^{99 \mathrm{~m}}$ Tc UBI for Monitoring Efficacy of Antibacterial Agents. ${ }^{99 \mathrm{~m}}$ Tc-UBI when injected into Staphylococcus-aureus-infected mice after treatment with various doses of cloxacillin and erythromycin showed inverse correlation between accumulation of the peptide at the site of infection and the dose of antibacterial agents. Good correlation was observed between the accumulation of ${ }^{99} \mathrm{~m}$ Tc-UBI and the number of viable bacteria. These results indicated the potential of the peptide for evaluating the efficacy of antibiotic therapy. However, minimum number of bacteria that can be detected was $10^{3}-10^{4}$, which is the limitation for monitoring the effects of the antibacterial agents [144]. Same conclusion was drawn in another study in which commonly used broadspectrum antibiotic ciprofloxacin was used in a rabbit model. It also revealed that the radiotracer can be used for monitoring efficacy and duration of antibiotic treatment [28].

4.8.12. Biodistribution in Humans. ${ }^{99 \mathrm{~m}} \mathrm{Tc}-\mathrm{UBI}$ was investigated in a biokinetic model to evaluate its feasibility as an infection imaging agent in humans. Whole body images from 6 children with suspected bone infection were acquired at 1 , 30, 120, 240 minutes and 24 hours after tracer administration. Regions of interest (ROIs) were drawn around source organs (heart, liver, kidneys, and bladder) on each time frame. The same set of ROIs was used for all 6 scans and the counts per minutes $(\mathrm{cpm})$ of each ROI were converted to activity using the conjugate view counting method. Counts were corrected by physical decay and by the background correction factor derived from preclinical phantom studies. The image sequence was used to extrapolate ${ }^{99 \mathrm{~m}} \mathrm{Tc}-\mathrm{UBI}$ time-activity curves in each organ and calculate the cumulated activity. Urine samples were used to obtain the cumulative percent of injected activity versus time renal elimination. The absorbed dose in organs was evaluated according to the general equation described in the MIRD formula. In addition, ${ }^{67} \mathrm{Ga}$-citrate images were obtained from all the patients and used as a control. Biokinetic data showed a fast blood clearance with a mean residence time of 0.52 hour. Approximately $85 \%$ of the injected activity was eliminated by renal clearance 24 hours after ${ }^{99 m}$ Tc-UBI administration. Images showed minimal accumulation in nontarget tissues with an average target/nontarget ratio of $2.18 \pm 0.74$ in positive lesions at 2 hours. All infection positive images were in agreement with those obtained with ${ }^{67} \mathrm{Ga}$-citrate. The mean radiation-absorbed dose calculated was $0.13 \mathrm{mGy} / \mathrm{MBq}$ for kidneys and the effective dose was $4.34 \times 10^{-3} \mathrm{mSv} / \mathrm{MBq}$ [145]. Biodistribution of the peptide was also studied in 3 normal subjects in another study by taking anterior and posterior whole body images and using geometric mean method. It was observed that the tracer mainly excreted through the kidneys into urinary bladder followed by liver with no other site of accumulation in the body (Figure 5) [27].

4.8.13. Bacterial Infection Detection in Humans with ${ }^{99 \mathrm{~m}} \mathrm{Tc}$ UBI 29-41. ${ }^{99 \mathrm{~m}}$ Tc UBI 29-41 showed good correlation for infection detection in humans when compared with ${ }^{67} \mathrm{Ga}$ imaging of the same subjects [145]. In another study the agent was tested in patients suffering from bone, soft tissue, or prosthesis infections and encouraging results were observed with overall sensitivity, specificity, and accuracy of $100 \%, 80 \%$, and $94.4 \%$, respectively. Maximum tracer accumulation was noted at 30 minutes after tracer injection (Figure 6) [29]. 


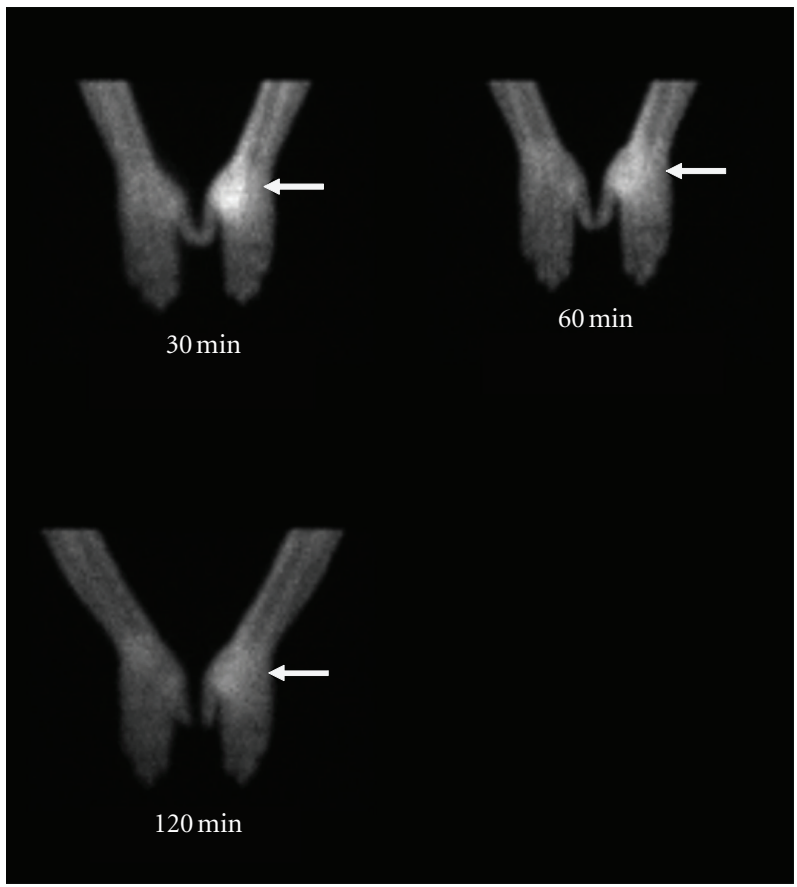

Figure 6: Positive 99m Tc-UBI 29-41 scan in a patient with infection in medial aspect of right hand (arrow). Maximum focal increased tracer uptake was seen at 30 minutes after tracer injection.

This peptide yielded fast and promising results in patients with suspected mediastinitis after cardiac surgery. Qualitative analysis correctly identified infection in 5/6 patients with proven mediastinitis on bacterial culture [146]. Fever of unknown origin (FUO) is also a diagnostic dilemma for physicians and surgeons. Antibiotics are blindly used without localizing the infective focus. This antimicrobial peptide revealed specificity of $95.35 \%$ for localizing infection and discarding sterile inflammation. Sensitivity was $97.52 \%$ with high accuracy [147]. Vertebral osteomyelitis is difficult to diagnose by noninvasive diagnostic modalities including CT, MRI, radionuclide bone scan, and X-Ray. Even ${ }^{67} \mathrm{Ga}$ scan is nonspecific test which is considered better than other diagnostic techniques. As UBI 29-41 has special affinity for binding to viable bacteria, this has been used for confirmation of vertebral infection which showed $100 \%$ sensitivity and $88 \%$ specificity [148]. Noninvasive diagnostic techniques including three-phase bone scan, MRI, and ${ }^{99 \mathrm{~m}} \mathrm{Tc}-\mathrm{UBI} 29-41$ scan for detection of osteomyelitis were compared. Antimicrobial peptide showed $100 \%$ accuracy with maximum mean target to nontarget ratio at 15 minutes after tracer injection, while three-phase bone scan and MRI revealed $90 \%$ and $75 \%$ accuracy, respectively. This study revealed superiority of antimicrobial peptide imaging over bone scan and MRI [149].

4.8.14. ${ }^{99 \mathrm{~m}} \mathrm{Tc}$-UBI Scan for Monitoring Efficacy of Antibiotic Treatment in Human Infections. As mentioned in animal studies, binding of ${ }^{99 \mathrm{~m}}$ Tc UBI $29-41$ to viable bacteria is proportional to their number in the infective focus. Intensity of tracer uptake decreased when number of viable bacteria was reduced. Therefore it was concluded that this tracer can be used for monitoring efficacy and duration of treatment
[28, 144]. Similar study for monitoring antibiotic therapy in patients with orthopaedic infections showed better results on quantitative analysis of scan at 30,60, and 120 minutes after tracer injection after 10-14, day interval with antibiotic treatment when compared with erythrocyte sedimentation rate, C-reactive protein, and radioisotope bone scan [150].

\section{Limitations of Antimicrobial Peptides}

5.1. Lack of Discrimination between Different Infectious Agents. ${ }^{99 \mathrm{~m}}$ Tc-labeled antimicrobial peptides bind to fungi in addition to bacterial cell membranes; however, infection either from bacteria or fungi can be differentiated from sterile inflammatory sites [24]. Similarly, there is nonuniform accumulation of radiolabeled peptides in different types of bacteria. Staphylococcus aureus showed more uptake than Escherichia coli which may be due to different mode of toxicity [27].

5.2. Lack of Detection of Intracellular Pathogens. Radiolabeled peptides bind to the cell membranes of the bacteria. However, if the bacteria are engulfed by the anti-inflammatory cells or become intracellular after invasion of the host immune cells, their detection would become difficult with scintigraphy [123].

5.3. Resistance against Antimicrobial Peptides. Major concern with use of the labeled antibiotics as specific infection localization tracers is the development of resistance. Similar situation may also be encountered with antimicrobial peptides. Some Gram-negative bacteria can modify the lipid-A moiety of the endotoxin [151]. Similarly Gram-positive bacteria can reduce negative charge of the bacterial surface 
by esterification of phospholipids of Staphylococcus aureus [152]. Inactivation of antimicrobial peptides by bacterial serine proteases can prevent intracellular accumulation of the peptides [153]. However, in multiple studies conducted with different radiolabeled antimicrobial peptides including UBI (29-41) have not revealed such evidence up till now.

\section{Conclusion}

The medical community often faces the dilemma of discrimination between infection and inflammation on medical as well as on surgical floors. Nonspecific radiotracers for localization of infection/inflammation do not solve the problem. Among the specific radiotracers for localization of infection, antibiotics gained more popularity due to easy availability, labeling, low cost, and high sensitivity. Among the labeled antibiotics ciprofloxacin was the most successful specific bacterial localization agent which showed sensitivity of $85.4 \%$ and specificity of $81.7 \%$ [117]. However, emerging antibiotic resistance against antibiotics is also associated with ciprofloxacin [154]. False uptake of ${ }^{99 \mathrm{~m}} \mathrm{Tc}$-ciprofloxacin in sterile inflammation is also a big disadvantage [14]. Due to nonspecific accumulation in inflammatory sites, this agent has been proposed for identifying the presence and distribution of inflammation in joints [18].

On the other hand, antimicrobial peptides labeled with isotopes are better specific infection localizing agents as they bind specifically to bacterial cell membranes. These tracers detect Gram-positive, Gram-negative bacteria, Candida albicans and Aspergillus Fumigatus infections. The amount of radiolabeled peptides at the site of infection depends on the number of viable organisms present at the focus. Recently investigated antimicrobial peptide, ubiquicidin UBI (29-41) has shown encouraging results in human clinical trials. This peptide can also be used for monitoring efficacy and duration of antibiotic treatment in patients which is very important issue from prophylactic, therapeutic, and socioeconomic point of view. No doubt, there are limitations attributed to synthesis/isolation of such peptides, labeling with isotopes, minimum detection limit of $10^{3}$ Colony-Forming Unit (CFU) of bacteria, and inability to distinguish between bacterial and fungal infections. In addition, different bacterial types reveal different tracer accumulation (Staphylococcus aureus versus Escherichia coli). Currently no evidence regarding resistance against antimicrobial peptides has been reported. Considering the merits and demerits of radiolabeled peptides and radiolabeled antibiotics, it can currently be concluded that radiolabeled peptides are better specific infection localizing agents.

\section{References}

[1] O. Levy, "Antimicrobial proteins and peptides of blood: templates for novel antimicrobial agents," Blood, vol. 96, no. 8, pp. 2664-2672, 2000.

[2] M. R. Yeaman, A. S. Ibrahim, J. E. J. Edwards, A. S. Bayer, and M. A. Ghannoum, "Thrombin-induced rabbit platelet microcidal protein is fungicidal in vitro," Antimicrob Agents Chemother, vol. 37, pp. 546-553, 1993.
[3] S. S. Das, A. V. Hall, D. W. Wareham, and K. E. Britten, "Infection imaging with radiopharmaceuticals in the 21st century," Brazilian Archives of Biology and Technology, vol. 45, pp. 25-37, 2002.

[4] F. H. M. Corstens and J. W. M. Van Der Meer, "Nuclear medicine's role in infection and inflammation," Lancet, vol. 354, no. 9180, pp. 765-770, 1999.

[5] A. M. Peters, H. J. Danpure, S. Osman et al., "Preliminary clinical experience with ${ }^{99 m}$ Tc-hexamethylpropylene-amineoxime for labelling leucocytes and imaging infection," The Lancet, vol. 2, pp. 945-949, 1986.

[6] A. M. Peters, "The utility of [ $\left.{ }^{99 m} \mathrm{Tc}\right] \mathrm{HMPAO}-$ leukocytes for imaging infection," Seminars in Nuclear Medicine, vol. 24, no. 2, pp. 110-127, 1994.

[7] S. Gratz, H. J. J. M. Rennen, O. C. Boerman et al., " ${ }^{99 m}$ TcHMPAO-labeled autologous versus heterologous leukocytes for imaging infection," Journal of Nuclear Medicine, vol. 43, no. 7, pp. 918-924, 2002.

[8] W. Becker and J. Meller, "The role of nuclear medicine in infection and inflammation," Lancet Infectious Diseases, vol. 1, no. 5, pp. 326-333, 2001.

[9] C. Love and C. J. Palestro, "Radionuclide imaging of infection," Journal of Nuclear Medicine Technology, vol. 32, no. 2, pp. 47-57, 2004.

[10] L. Filippi and O. Schillaci, "Usefulness of hybrid SPECT/CT in ${ }^{99 m}$ TC-HMPAO-labeled leukocyte scintigraphy for bone and joint infections," Journal of Nuclear Medicine, vol. 47, no. 12, pp. 1908-1913, 2006.

[11] R. Bar-Shalom, N. Yefremov, L. Guralnik et al., "SPECT/CT using $67 \mathrm{Ga}$ and $111 \mathrm{In}$-labeled leukocyte scintigraphy for diagnosis of infection," Journal of Nuclear Medicine, vol. 47, no. 4, pp. 587-594, 2006.

[12] N. Dumarey, D. Egrise, D. Blocklet et al., "Imaging infection with 18F-FDG-labeled leukocyte PET/CT: initial experience in 21 patients," Journal of Nuclear Medicine, vol. 47, no. 4, pp. 625-632, 2006.

[13] B. Fournier, X. Zhao, T. Lu, K. Drlica, and D. C. Hooper, "Selective targeting of topoisomerase IV and DNA gyrase in Stphylococcus aureus: different patterns of quinolone-induced inhibition of DNA Synthesis," Antimicrob Agents Chemother, vol. 44, pp. 2160-2165, 2000.

[14] Z. Yapar, M. Kibar, A. F. Yapar, E. Toğrul, U. Kayaselçuk, and Y. Sarpel, "The efficacy of technetium-99m ciprofloxacin (Infecton) imaging in suspected orthopaedic infection: a comparison with sequential bone/gallium imaging," European Journal of Nuclear Medicine, vol. 28, no. 7, pp. 822-830, 2001.

[15] K. Sonmezoglu, M. Sonmezoglu, M. Halac et al., "Usefulness of ${ }^{99 m} \mathrm{Tc}$-ciprofloxacin (infecton) scan in diagnosis of chronic orthopedic infections: comparative study with ${ }^{99 m}$ Tc-HMPAO leukocyte scintigraphy," Journal of Nuclear Medicine, vol. 42, no. 4, pp. 567-574, 2001.

[16] M. J. Larikka, A. K. Ahonen, O. Niemela et al., "99m Tc-ciproflaxacin (infection) imaging in the diagnosis of knee prosthesis infections," Nuclear Medicine Communications, vol. 23, pp. 167-170, 2002.

[17] L. Sarda, A. C. Crémieux, Y. Lebellec et al., "Inability of ${ }^{99 m}$ Tc-ciprofloxacin scintigraphy to discriminate between septic and sterile osteoarticular diseases," Journal of Nuclear Medicine, vol. 44, no. 6, pp. 920-926, 2003.

[18] T. Appelboom, P. Emery, L. Tant, N. Dumarey, and A. Schoutens, "Evaluation of technetium-99m-ciprofloxacin (infection) for detecting sites of inflammation in arthritis," Rheumatology, vol. 42, no. 10, pp. 1179-1182, 2003. 
[19] M. E. Jones, N. M. Boenink, J. Verhoef, K. Kohrer, and F. J. Schmitz, "Multiple mutations conferring ciprofloxacin resistance in staphylococcus aureus demonstrate long-term stability in an antibiotic free environment," Journal of Antimicrobial Chemotherapy, vol. 45, pp. 353-356, 2000.

[20] M. Zasloff, "Antimicrobial peptides of multicellular organisms," Nature, vol. 415, no. 6870, pp. 389-395, 2002.

[21] M. M. Welling, P. H. Nibbering, A. Paulusma-Annema, P. S. Hiemstra, E. K. J. Pauwels, and W. Calame, "Imaging of bacterial infections with ${ }^{99 m}$ Tc-labeled human neutrophil peptide-1," Journal of Nuclear Medicine, vol. 40, no. 12, pp. 2073-2080, 1999.

[22] P. S. Hiemstra, M. T. Van Den Barselaar, M. Roest, P. H. Nibbering, and R. Van Furth, "Ubiquicidin, a novel murine microbicidal protein present in the cytosolic fraction of macrophages," Journal of Leukocyte Biology, vol. 66, no. 3, pp. 423-428, 1999.

[23] M. M. Welling, S. Mongera, A. Lupetti et al., "Radiochemical and biological characteristics of ${ }^{99 m}$ Tc-UBI 29-41 for imaging of bacterial infections," Nuclear Medicine and Biology, vol. 29, no. 4, pp. 413-422, 2002.

[24] M. M. Welling, A. Lupetti, H. S. Balter et al., " ${ }^{99 m}$ Tc-labeled antimicrobial peptides for detection of bacterial and Candida albicans infections," Journal of Nuclear Medicine, vol. 42, no. 5, pp. 788-794, 2001.

[25] R. M. Epand and H. J. Vogel, "Diversity of antimicrobial peptides and their mechanisms of action," Biochimica et Biophysica Acta, vol. 1462, no. 1-2, pp. 11-28, 1999.

[26] M. Edgerton, S. E. Koshlukova, T. E. Lo, B. G. Chrzan, R. M. Straubinger, and P. A. Raj, "Candidacidal activity of salivary histatins: identification of a histatin 5-binding protein on Candida albicans," Journal of Biological Chemistry, vol. 273, no. 32, pp. 20438-20447, 1998.

[27] M. S. Akhtar, J. Iqbal, M. A. Khan et al., " ${ }^{\circ 9 m}$ Tc-labeled antimicrobial peptide ubiquicidin (29-41) accumulates less in Escherichia coli infection than in Staphlococcus aureus infection," Journal of Nuclear Medicine, vol. 45, no. 5, pp. 849856, 2004.

[28] M. S. Akhtar, M. E. Khan, B. Khan et al., "An imaging analysis of ${ }^{99 m}$ Tc-UBI (29-41) uptake in S. aureus infected thighs of rabbits on ciprofloxacin treatment," European Journal of Nuclear Medicine and Molecular Imaging, vol. 35, no. 6, pp. 1056-1064, 2008.

[29] M. S. Akhtar, A. Qaisar, J. Irfanullah et al., "Antimicrobial peptide ${ }^{99 m}$ Tc-Ubiquicidin 29-41 as human infection-imaging agent: clinical trial," Journal of Nuclear Medicine, vol. 46, no. 4, pp. 567-573, 2005.

[30] Y. Ito, S. Okuyama, T. Awano, K. Takahashi, and T. Sato, "Diagnostic evaluation of $67 \mathrm{Ga}$ scanning of lung cancer and other diseases.," Radiology, vol. 101, no. 2, pp. 355-362, 1971.

[31] R. D. Neuman and J. G. McAfee, "Gallium-67 imaging in infection," in Diagnostic Nuclear Medicine, M. P. Sandler, J. A. Patton, R. E. Coleman, A. Gottschalk, F. J. Wackers, and P. B. Hoffer, Eds., pp. 1493-1507, Williams and Wilkins, Baltimore, Md, USA, 3rd edition, 1996.

[32] M. F. Tsan, "Mechanism of gallium-67 accumulation in inflammatory lesions," Journal of Nuclear Medicine, vol. 26, no. 1, pp. 88-92, 1985.

[33] R. K. Zeman and T. W. Ryerson, "The value of bowel preparation in Ga-67 citrate scanning: concise communication," Journal of Nuclear Medicine, vol. 18, no. 9, pp. 886-889, 1977.

[34] O. James, E. J. Wood, and S. Sherlock, "67Gallium scanning in the diagnosis of liver disease," Gut, vol. 15, no. 5, pp. 404410, 1974.
[35] D. Front, O. Israel, R. Epelbaum et al., "Ga-67 SPECT before and after treatment of lymphoma," Radiology, vol. 175, no. 2, pp. 515-519, 1990.

[36] C. J. Palestro, "The current role of gallium imaging in infection," Seminars in Nuclear Medicine, vol. 24, no. 2, pp. 128141, 1994.

[37] E. V. Staab and W. H. McCartney, "Role of Gallium 67 in inflammatory disease," Seminars in Nuclear Medicine, vol. 8, no. 3, pp. 219-234, 1978.

[38] M. A. Auler, S. Bagg, and L. Gordon, "The role of nuclear medicine in imaging infection," Seminars in Roentgenology, vol. 42, no. 2, pp. 117-121, 2007.

[39] A. J. Fischman, R. H. Rubin, J. A. White et al., "Localization of Fc and Fab fragments of nonspecific polyclonal IgG at focal sites of inflammation," Journal of Nuclear Medicine, vol. 31, no. 7, pp. 1199-1205, 1990.

[40] A. J. Fischman, A. J. Fucello, J. L. Pellegrino-Gensey et al., "Effect of carbohydrate modification on the localization of human polyclonal IgG at focal sites of bacterial infection," Journal of Nuclear Medicine, vol. 33, no. 7, pp. 1378-1382, 1992.

[41] M. W. Nijhof, W. J. G. Oyen, A. Van Kämpen, R. A. M. J. Ciaessens, J. W. M. Van Der Meer, and F. H. M. Corstens, "Evaluation of infections of the locomotor system with indium-111 -labeled human IgG scintigraphy," Journal of Nuclear Medicine, vol. 38, no. 8, pp. 1300-1305, 1997.

[42] J. R. Buscombe, W. J. G. Oyen, A. Grant et al., "Indium-111labeled polyclonal human immunoglobulin: identifying focal infection in patients positive for human immunodeficiency virus," Journal of Nuclear Medicine, vol. 34, no. 10, pp. 16211625, 1993.

[43] L. Mairal, P. A. De Uma, J. Martin-Comin et al., "Simultaneous administration of $111 \mathrm{In}$-human immunoglobulin and ${ }^{99 m} \mathrm{Tc}$-HMPAO labelled leucocytes in inflammatory bowel disease," European Journal of Nuclear Medicine, vol. 22, no. 7, pp. 664-670, 1995.

[44] W. Becker, J. Bair, T. Behr et al., "Detection of softtissue infections and osteomyelitis using a technetium- 99mlabeled anti-granulocyte monoclonal antibody fragment," Journal of Nuclear Medicine, vol. 35, no. 9, pp. 1436-1443, 1994.

[45] O. C. Boerman, G. Storm, W. J. G. Oyen et al., "Sterically stabilized liposomes labeled with Indium-111 to image focal infection," Journal of Nuclear Medicine, vol. 36, no. 9, pp. 1639-1644, 1995.

[46] P. Laverman, E. T. M. Dams, W. J. G. Oyen et al., "A novel method to label liposomes with ${ }^{99 m} \mathrm{Tc}$ by the hydrazino nicotinyl derivative," Journal of Nuclear Medicine, vol. 40, no. 1, pp. 192-197, 1999.

[47] E. T. M. Dams, W. J. G. Oyen, O. C. Boerman et al., " PEG liposomes for the scintigraphic detection of infection and inflammation: clinical evaluation," Journal of Nuclear Medicine, vol. 41, no. 4, pp. 622-630, 2000.

[48] D. J. Hnatowich, F. Virzi, and M. Rusckowski, "Investigations of avidin and biotin for imaging applications," Journal of Nuclear Medicine, vol. 28, no. 8, pp. 1294-1302, 1987.

[49] M. Rusckowski, B. Fritz, and D. J. Hnatowich, "Localization of infection using streptavidin and biotin: an alternative to nonspecific polyclonal immunoglobulin," Journal of Nuclear Medicine, vol. 33, no. 10, pp. 1810-1815, 1992.

[50] A. Samuel, G. Paganelli, R. Chiesa et al., "Detection of prosthetic vascular graft infection using avidin/indium-111-biotin scintigraphy," Journal of Nuclear Medicine, vol. 37, no. 1, pp. 55-61, 1996. 
[51] M. Rusckowski, G. Paganelli, D. J. Hnatowich et al., "Imaging osteomyelitis with streptavidin and Indium-111-labeled biotin," Journal of Nuclear Medicine, vol. 37, no. 10, pp. 16551662, 1996.

[52] C. J. Palestro and M. A. Torres, "Radionuclide imaging of nonosseous infection," Quarterly Journal of Nuclear Medicine, vol. 43, no. 1, pp. 46-60, 1999.

[53] E. Outwater, E. Oates, and R. C. Sarno, "Indium-111-labeled leukocyte scintigraphy: diagnosis of subperiosteal abscesses complicating osteomyelitis in a child," Journal of Nuclear Medicine, vol. 29, no. 11, pp. 1871-1874, 1988.

[54] F. L. Datz and D. A. Thorne, "Cause and significance of cold bone defects on Indium-111-labeled leukocyte imaging," Journal of Nuclear Medicine, vol. 28, no. 5, pp. 820-823, 1987.

[55] K. Uno, N. Matsui, and K. Nohira, "Indium-111 leukocyte imaging in patients with rheumatoid arthritis," Journal of Nuclear Medicine, vol. 27, no. 3, pp. 339-344, 1986.

[56] D. S. Schauwecker, H. M. Park, R. W. Burt, B. H. Mock, and H. N. Wellman, "Combined bone scintigraphy and indium111 leukocyte scans in neuropathic foot disease," Journal of Nuclear Medicine, vol. 29, no. 10, pp. 1651-1655, 1988.

[57] L. M. Lamki, L. P. Kasi, and T. P. Haynie, "Localization of Indium-111 leukocytes in noninfected neoplasms," Journal of Nuclear Medicine, vol. 29, no. 12, pp. 1921-1926, 1988.

[58] C. J. Palestro, H. H. Mehta, M. Patel et al., "Marrow versus infection in the Charcot joint: indium-111 leukocyte and technetium-99m sulfur colloid scintigraphy," Journal of $\mathrm{Nu}$ clear Medicine, vol. 39, no. 2, pp. 346-350, 1998.

[59] W. J. G. Oyen, R. A. M. J. Claessens, J. W. M. Van der Meer, and F. H. M. Corstens, "Detection of subacute infectious foci with indium-111-labeled autologous leukocytes and indium111-labeled human nonspecific immunoglobulin G: a prospective comparative study," Journal of Nuclear Medicine, vol. 32, no. 10, pp. 1854-1860, 1991.

[60] J. G. McAfee, G. Gagne, G. Subramanian, and R. F. Schneider, "The localization of indium-111-leukocytes, gallium-67polyclonal IgG and other radioactive agents in acute focal inflammatory lesions," Journal of Nuclear Medicine, vol. 32, no. 11, pp. 2126-2131, 1991.

[61] C. J. Palestro, C. K. Kim, A. J. Swyer, S. Vallabhajosula, and S. J. Goldsmith, "Radionuclide diagnosis of vertebral osteomyelitis: indium-111-leukocyte and technetium-99m-methylene diphosphonate bone scintigraphy," Journal of Nuclear Medicine, vol. 32, no. 10, pp. 1861-1865, 1991.

[62] F. L. Datz, "Indium-111-labeled leukocytes for the detection of infection: current status," Seminars in Nuclear Medicine, vol. 24, no. 2, pp. 92-109, 1994.

[63] S. L. Kipper, "Radiolabelled leukocyte imaging of the abdomen," in Nuclear Medicine Annual, L. M. Freeman, Ed., pp. 81-126, Raven Press, New York, NY, USA, 1995.

[64] J. H. Thrall and H. A. Ziessman, "Infection and inflammation," in Nuclear Medicine: The Requisites, J. H. Thrall, Ed., pp. 167-192, Mosby, 2nd edition, 2001.

[65] M. E. Roddie, A. M. Peters, H. J. Danpure et al., "Inflammation: imaging with Tc-99m HMPAO-labeled leukocytes," Radiology, vol. 166, no. 3, pp. 767-772, 1988.

[66] M. Vorne, I. Soini, T. Lantto, and S. Paakkinen, "Technetium99m HM-PAO-labeled leukocytes in detection of inflammatory lesions: comparison with Gallium-67 citrate," Journal of Nuclear Medicine, vol. 30, no. 8, pp. 1332-1336, 1989.

[67] I. Hovi, M. Taavitsainen, T. Lantto, M. Vorne, R. Paul, and K. Remes, "Technetium-99m-HMPAO-labeled leukocytes and technetium-99m-labeled human polyclonal immunoglobulin $\mathrm{G}$ in diagnosis of focal purulent disease," Journal of $\mathrm{Nu}$ clear Medicine, vol. 34, no. 9, pp. 1428-1434, 1993.

[68] E. H. Lantto, T. J. Lantto, and M. Vorne, "Fast diagnosis of abdominal infections and inflammations with technetium-99m-HMPAO labeled leukocytes," Journal of Nuclear Medicine, vol. 32, no. 11, pp. 2029-2034, 1991.

[69] E. H. Lantto, T. J. Lantto, and M. Vorne, "Fast diagnosis of abdominal infections and inflammations with technetium-99m-HMPAO labeled leukocytes," Journal of Nuclear Medicine, vol. 32, no. 11, pp. 2029-2034, 1991.

[70] F. Palermo, F. Boccaletto, A. Paolin et al., "Comparison of technetium-99m-MDP, technetium-99-m-WBC and technetium- 99m-HIG in musculoskeletal inflammation," Journal of Nuclear Medicine, vol. 39, no. 3, pp. 516-521, 1998.

[71] W. Becker, U. Borst, W. Fischbach, B. Pasurka, R. Schafer, and W. Borner, "Kinetic data of in-vivo labeled granulocytes in humans with a murine Tc-99m-labelled monoclonal antibody," European Journal of Nuclear Medicine, vol. 15, no. 7, pp. 361-366, 1989.

[72] W. S. Becker, A. Saptogino, and F. G. Wolf, "The single late 99Tcm granulocyte antibody scan in inflammatory diseases," Nuclear Medicine Communications, vol. 13, no. 3, pp. 186192, 1992.

[73] W. Becker, J. Bair, T. Behr et al., "Detection of soft-tissue infections and osteomyelitis using a technetium- 99m-labeled anti-granulocyte monoclonal antibody fragment," Journal of Nuclear Medicine, vol. 35, no. 9, pp. 1436-1443, 1994.

[74] M. L. Thakur, C. S. Marcus, P. Henneman et al., "Imaging inflammatory diseases with neutrophil-specific technetium99m-labeled monoclonal antibody anti-SSEA-1," Journal of Nuclear Medicine, vol. 37, no. 11, pp. 1789-1795, 1996.

[75] S. L. Kipper, E. B. Rypins, D. G. Evans, M. L. Thakur, T. D. Smith, and B. Rhodes, "Neutrophil-specific ${ }^{99 m}$ Tc-labeled anti-CD 15 monoclonal antibody imaging for diagnosis of equivocal appendicitis," Journal of Nuclear Medicine, vol. 41, no. 3, pp. 449-455, 2000.

[76] S. Gratz, T. Behr, A. Herrmann et al., "Intraindividual comparison of ${ }^{99 m} \mathrm{Tc}$-labelled anti-SSEA-1 antigranulocyte antibody and ${ }^{99 m} \mathrm{Tc}-\mathrm{HMPAO}$ labelled white blood cells for the imaging of infection," European Journal of Nuclear Medicine, vol. 25, no. 4, pp. 386-393, 1998.

[77] W. Becker, D. M. Goldenberg, and F. Wolf, "The use of monoclonal antibodies and antibody fragments in the imaging of infectious lesions," Seminars in Nuclear Medicine, vol. 24, no. 2, pp. 142-153, 1994.

[78] A. J. Fischman, M. C. Pike, D. Kroon et al., "Imaging focal sites of bacterial infection in rats with indium-111- labeled chemotactic peptide analogs," Journal of Nuclear Medicine, vol. 32, no. 3, pp. 483-491, 1991.

[79] J. W. Babich, W. Graham, S. A. Barrow et al., "Technetium99m-labeled chemotactic peptides: comparison with Indium-111- labeled white blood cells for localizing acute bacterial infection in the rabbit," Journal of Nuclear Medicine, vol. 34, no. 12, pp. 2176-2181, 1993.

[80] A. J. Fischman, D. Rauh, H. Solomon et al., "In vivo bioactivity and biodistribution of chemotactic peptide analogs in nonhuman primates," Journal of Nuclear Medicine, vol. 34, no. 12, pp. 2130-2134, 1993.

[81] J. W. Babich, Q. Dong, W. Graham et al., "A novel high affinity chemotactic peptide antagonist for infection imaging," Journal of Nuclear Medicine, vol. 38: 268, 1997. 
[82] A. D. Luster, "Mechanisms of disease: chemokines-chemotactic cytokines that mediate inflammation," New England Journal of Medicine, vol. 338, no. 7, pp. 436-445, 1998.

[83] C. J. Van der Laken, O. C. Boerman, W. J. G. Oyen et al., "Specific targeting of infectious foci with radioiodinated human recombinant interleukin-1 in an experimental model," European Journal of Nuclear Medicine, vol. 22, no. 11, pp. 1249-1255, 1995.

[84] C. J. vanderLaken, O. C. Boerman, W. J. G. Oyen et al., “Comparison of radiolabeled human recombinant interleukin-1 with its receptor antagonist in a model of infection," European Journal of Nuclear Medicine, vol. 22: 916, 1995.

[85] A. Signore, M. Chianelli, A. Annovazzi et al., "123I-Interleukin-2 scintigraphy for in vivo assessment of intestinal mononuclear cell infiltration in Crohn's disease," Journal of Nuclear Medicine, vol. 41, no. 2, pp. 242-249, 2000.

[86] A. Signore, M. Chianelli, A. Annovazzi et al., "Imaging active lymphocytic infiltration in coeliac disease with iodine- 123interleukin-2 and the response to diet," European Journal of Nuclear Medicine, vol. 27, no. 1, pp. 18-24, 2000.

[87] M. D. Gross, B. Shapiro, R. S. Skinner, P. Shreve, L. M. Fig, and R. V. Hay, "Scintigraphy of osteomyelitis in man with human recombinant interleukin-8," Journal of Nuclear Medicine, vol. 37: 25, 1996.

[88] R. V. Hay, R. S. Skinner, O. C. Newman et al., "Scintigraphy of acute inflammatory lesions in rats with radliolabelled recombinant human interleukin-8," Nuclear Medicine Communications, vol. 18, no. 4, pp. 367-378, 1997.

[89] C. J. Van Der Laken, O. C. Boerman, W. J. G. Oyen, M. T. P. Van De Ven, J. W. M. Van Der Meer, and F. H. M. Corstens, "Radiolabeled interleukin-8: specific scintigraphic detection of infection within a few hours," Journal of Nuclear Medicine, vol. 41, no. 3, pp. 463-469, 2000.

[90] H. J. J. M. Rennen, O. C. Boernan, W. J. G. Oyen, J. W. M. Van der Meer, and F. H. M. Corstens, "Specific and rapid scintigraphic detection of infection with ${ }^{99 m}$ Tc-labeled interleukin-8," Journal of Nuclear Medicine, vol. 42, no. 1, pp. $117-123,2001$.

[91] S. Gratz, H. J. J. M. Rennen, O. C. Boerman, W. J. G. Oyen, and F. H. M. Corstens, "Rapid imaging of experimental colitis with ${ }^{99 m} \mathrm{Tc}$-interleukin-8 in rabbits," Journal of Nuclear Medicine, vol. 42, no. 6, pp. 917-923, 2001.

[92] B. R. Moyer, S. Vallabhajosula, J. Lister-James et al., "Technetium-99m-White Blood Cell-Specific Imaging Agent Developed from Platelet Factor 4 to Detect Infection," Journal of Nuclear Medicine, vol. 37, no. 4-6, pp. 673-679, 1996.

[93] C. J. Palestro, M. B. Tomas, K. K. Bhargava et al., "Tc-99m $\mathrm{P} 483 \mathrm{H}$ for imaging infection: phase 2 multicenter trial results," Journal of Nuclear Medicine, vol. 40:15, 1999.

[94] G. I. Bell, C. F. Burant, J. Takeda, and G. W. Gould, "Structure and function of mammalian facilitative sugar transporters," Journal of Biological Chemistry, vol. 268, no. 26, pp. 1916119164, 1993.

[95] E. K. J. Pauwels, M. J. Ribeiro, J. H. M. B. Stoot, V. R. McCready, M. Bourguignon, and B. Mazière, "FDG accumulation and tumor biology," Nuclear Medicine and Biology, vol. 25, no. 4, pp. 317-322, 1998.

[96] H. Zhuang and A. Alavi, "18-Fluorodeoxyglucose positron emission tomographic imaging in the detection and monitoring of infection and inflammation," Seminars in Nuclear Medicine, vol. 32, no. 1, pp. 47-59, 2002.

[97] J. Y. Paik, K. H. Lee, S. C. Yearn, Y. Choi, and B. T. Kim, "Augmented 18F-FDG uptake in activated monocytes occurs during the priming process and involves tyrosine kinases and protein kinase C," Journal of Nuclear Medicine, vol. 45, no. 1, pp. 124-128, 2004.

[98] P. D. Shreve, Y. Anzai, and R. L. Wahl, "Pitfalls in oncologic diagnosis with FDG PET imaging: physiologic and benign variants," Radiographics, vol. 19, no. 1, pp. 61-77, 1999.

[99] T. Nakahara, H. Fujii, M. Ide et al., "FDG uptake in the morphologically normal thymus: comparison of FDG position emission tomography and CT," British Journal of Radiology, vol. 74, pp. 821-824, 2001.

[100] C. Love, M. B. Tomas, G. G. Tronco, and C. J. Palestro, "FDG PET of infection and inflammation," Radiographics, vol. 25, no. 5, pp. 1357-1368, 2005.

[101] A. Guhlmann, D. Brecht-Krauss, G. Suger et al., "Fluorine18-FDG PET and technetium-99m antigranulocyte antibody scintigraphy in chronic osteomyelitis," Journal of Nuclear Medicine, vol. 39, no. 12, pp. 2145-2152, 1998.

[102] Y. Sugawara, D. K. Braun, P. V. Kison, J. E. Russo, K. R. Zasadny, and R. L. Wahl, "Rapid detection of human infections with fluorine-18 fluorodeoxyglucose and positron emission tomography: preliminary results," European Journal of Nuclear Medicine, vol. 25, no. 9, pp. 1238-1243, 1998.

[103] R. F. Yen, Y. C. Chen, Y. W. Wu, M. H. Pan, and S. C. Chang, "Using 18-fluoro-2-deoxyglucose position emission tomography in detecting infectious endocarditis/endoarteritis: a preliminary report," Academic Radiology, vol. 11, pp. 316321, 2004.

[104] A. Guhlmann, D. Brecht-Krauss, G. Suger et al., "Chronic osteomyelitis: detection with FDG PET and correlation with histopathologic findings," Radiology, vol. 206, no. 3, pp. 749754, 1998.

[105] T. Kälicke, A. Schmitz, J. H. Risse et al., "Fluorine-18 fluorodeoxyglucose PET in infectious bone diseases: results of histologically confirmed cases," European Journal of Nuclear Medicine, vol. 27, no. 5, pp. 524-528, 2000.

[106] K. D. M. Stumpe, H. Dazzi, A. Schaffner, and G. K. Von Schulthess, "Infection imaging using whole-body FDG-PET," European Journal of Nuclear Medicine, vol. 27, no. 7, pp. 822832, 2000.

[107] M. Schiesser, K. D. M. Stumpe, O. Trentz, T. Kossmann, and G. K. Von Schulthess, "Detection of metallic implant-associated infections with FDG PET in patients with trauma: correlation with microbiologic results," Radiology, vol. 226, no. 2, pp. 391-398, 2003.

[108] C. Love and C. J. Palestro, "18F-FDG and 67Ga-SPECT imaging in suspected vertebral osteomyelitis: an intraindividual comparison," Journal of Nuclear Medicine, vol. 45, supplement: 148, 2003.

[109] S. Yamada, K. Kubota, R. Kubota, T. Ido, and N. Tamahashi, "High accumulation of fluorine-18-fluorodeoxyglucose in turpentine-induced inflammatory tissue," Journal of Nuclear Medicine, vol. 36, no. 7, pp. 1301-1306, 1995.

[110] Z. Keidar, D. Militianu, E. Melamed, R. Bar-Shalom, and O. Israel, "The diabetic foot: initial experience with 18F-FDG PET/CT," Journal of Nuclear Medicine, vol. 46, no. 3, pp. 444449, 2005.

[111] A. Kjaer, A. M. Lebech, A. Eigtved, and L. Højgaard, "Fever of unknown origin: prospective comparison of diagnostic value of 18F-FDG PET and 111In-granulocyte scintigraphy," European Journal of Nuclear Medicine and Molecular Imaging, vol. 31, no. 5, pp. 622-626, 2004.

[112] D. C. Hooper, J. S. Wolfson, E. Y. Ng, and M. N. Swartz, "Mechanisms of action of and resistance to ciprofloxacin," American Journal of Medicine, vol. 82, no. 4, pp. 12-20, 1987. 
[113] S. Vinjamuri, A. V. Hall, K. K. Solanki et al., "Comparison of ${ }^{99 m} \mathrm{Tc}$ infecton imaging with radiolabelled white-cell imaging in the evaluation of bacterial infection," Lancet, vol. 347, no. 8996, pp. 233-235, 1996.

[114] A. V. Hall, K. K. Solanki, S. Vinjamuri et al., "Evaluation of the efficacy of ${ }^{99 m} \mathrm{Tc}$-Infecton: a novel agent for detecting sites of infection," Journal of Clinical Pathology, vol. 51, pp. 215219, 1996.

[115] J. L. Martinez, A. Alonso, J. M. Gonez-Gomez, and F. Baquero, "Quinolone resistance by mutations in chromosomal gyrase genes," Journal of Antimicrobial Chemotherapy, vol. 42, pp. 683-671, 1998.

[116] F. De Winter, C. Van de Wiele, F. Dumont et al., "Biodistribution and dosimetry of ${ }^{99 m} \mathrm{Tc}$-ciprofloxacin, a promising agent for the diagnosis of bacterial infection," European Journal of Nuclear Medicine, vol. 28, no. 5, pp. 570-574, 2001.

[117] K. E. Britton, S. Vinjamuri, A. V. Hall et al., "Clinical evaluation of technetium-99m infecton for the localisation of bacterial infection," European Journal of Nuclear Medicine, vol. 24, no. 5, pp. 553-556, 1997.

[118] K. E. Britton, D. W. Wareham, S. S. Das et al., "Imaging bacterial infection with ${ }^{99 m}$ Tc-Ciprofloxacin (infecton)," Journal of Clinical Pathology, vol. 55, pp. 817-823, 2002.

[119] A. K. Singh, J. Verma, A. Bhatnagar, and A. Ali, " $99 m$ Tclabelled sparfloxacin: a specific infection imaging agent," World Journal of Nuclear Medicine, vol. 1, pp. 103-109, 2003.

[120] R. H. Siaens, H. J. Rennen, O. C. Boerman, R. Dierckx, and G. Slegers, "Synthesis and comparison of ${ }^{99 \mathrm{~m}} \mathrm{Tc}$-enrofloxacin and ${ }^{99 m}$ Tc-ciprofloxacin," Journal of Nuclear Medicine, vol. 45, no. 12, pp. 2088-2094, 2004.

[121] V. Gomes Barreto, F. Iglesias, M. Roca, F. Tabau, and J. Martin-Comin, "Labelling of cefizoxime with ${ }^{99 m} \mathrm{Tc}$," Revista Española de Medicina Nuclear, vol. 19, pp. 479-483, 2000.

[122] J. Verma, A. k. Singh, A. Bhatnagar et al., "Radio-labeling of Ethambutol with technetium-99m and its evaluation for detection of tuberculosis," World Journal of Nuclear Medicine, vol. 4, pp. 35-46, 2005.

[123] A. K. Singh, J. Verma, A. Bhatnagar, S. Sen, and M. Bose, "Tc99m isoniazid: a specific agent for diagnosis of tuberculosis," World Journal of Nuclear Medicine, vol. 2, pp. 292-305, 2003.

[124] A. Lupetti, M. M. Welling, U. Mazzi, P. H. Nibbering, and E. K. Pauwels, "Technetium-99m labelled fluconazole and antimicrobial peptides for imaging of Candida albicans and Aspergillus fumigatus infections," European Journal of Nuclear Medicine, vol. 29, no. 5, pp. 674-679, 2002.

[125] A. Lupetti, M. M. Welling, E. K. J. Pauwels, and P. H. Nibbering, "Radiolabelled antimicrobial peptides for infection detection," Lancet Infectious Diseases, vol. 3, no. 4, pp. 223229, 2003.

[126] A. J. Fischman, J. W. Babich, and H. W. Strauss, "A ticket to ride: peptide radiopharmaceuticals," Journal of Nuclear Medicine, vol. 34, no. 12, pp. 2253-2263, 1993.

[127] D. Blok, R. I. J. Feitsma, P. Vermeij, and E. J. K. Pauwels, "Peptide radiopharmaceuticals in nuclear medicine," European Journal of Nuclear Medicine, vol. 26, no. 11, pp. 1511$1519,1999$.

[128] P. H. Nibbering, M. M. Welling, P. J. Van Den Broek, K. E. Van Wyngaarden, E. K. J. Pauwels, and W. Calame, "Radiolabelled antimicrobial peptides for imaging of infections: a review," Nuclear Medicine Communications, vol. 19, no. 12, pp. 11171121, 1998.

[129] R. M. Epand and H. J. Vogel, "Diversity of antimicrobial peptides and their mechanisms of action," Biochimica et Biophysica Acta, vol. 1462, no. 1-2, pp. 11-28, 1999.
[130] A. Lupetti, P. H. Nibbering, M. M. Welling, and E. K. J. Pauwels, "Radiopharmaceuticals: new antimicrobial agents," Trends in Biotechnology, vol. 21, no. 2, pp. 70-73, 2003.

[131] S. M. Okarvi, "Recent developments in 99Tcm-labelled peptide-based radiopharmaceuticals: an overview," Nuclear Medicine Communications, vol. 20, no. 12, pp. 1093-1112, 1999.

[132] E. K. J. Pauwels, M. M. Welling, R. I. J. Feitsma, D. E. Atsma, and W. Nieuwenhuizen, "The labeling of proteins and LDL with ${ }^{99 m}$ Tc: a new direct method employing KBH4 and stannous chloride," Nuclear Medicine and Biology, vol. 20, no. 7, pp. 825-833, 1993.

[133] M. M. Welling, A. Paulusma-Annema, H. S. Balter, E. K. J. Pauwels, and P. H. Nibbering, "Technetium-99m labelled antimicrobial peptides discriminate between bacterial infections and sterile inflammations," European Journal of Nuclear Medicine, vol. 27, no. 3, pp. 292-301, 2000.

[134] M. M. Welling, P. S. Hiemstra, M. T. Van Den Barselaar et al., "Antibacterial activity of human neutrophil defensins in experimental infections in mice is accompanied by increased leukocyte accumulation," Journal of Clinical Investigation, vol. 102, no. 8, pp. 1583-1590, 1998.

[135] M. M. Welling, P. H. Nibbering, A. Paulusma-Annema, P. S. Hiemstra, E. K. J. Pauwels, and W. Calame, "Imaging of bacterial infections with ${ }^{99 m}$ Tc-labeled human neutrophil peptide-1," Journal of Nuclear Medicine, vol. 40, no. 12, pp. 2073-2080, 1999.

[136] P. H. Nibbering, M. M. Welling, A. Paulusma-Annema, M. T. vandenBarselaar, and E. K. J. Pauwels, "Monitoring the efficacy of antibacterial treatments of infections with Tc-99m labeled antimicrobial peptides," Nuclear Medicine Communications, vol. 21, pp. 575-576, 2000.

[137] P. S. Hiemstra, M. T. Van Den Barselaar, M. Roest, P. H. Nibbering, and R. Van Furth, "Ubiquicidin, a novel murine microbicidal protein present in the cytosolic fraction of macrophages," Journal of Leukocyte Biology, vol. 66, no. 3, pp. 423-428, 1999.

[138] G. Ferro-Flores, C. Arteaga De Murphy, M. Pedraza-López et al., "In vitro and in vivo assessment of ${ }^{99 \mathrm{~m}} \mathrm{Tc}$-UBI specificity for bacteria," Nuclear Medicine and Biology, vol. 30, no. 6, pp. 597-603, 2003.

[139] D. Salber, J. Gunawan, K.-J. Langen et al., "Comparison of ${ }^{99 m} \mathrm{Tc}$-and $18 \mathrm{~F}$-ubiquicidin autoradiography to anti-staphylococcus aureus immunoflorescence in rat muscle abscesses," Journal of Nuclear Medicine, vol. 49, pp. 995-999, 2008.

[140] L. Sarda-Mantel, A. Saleh-Mghir, M. M. Welling et al., "Evaluation of ${ }^{99 m}$ Tc-UBI 29-41 scintigraphy for specific detection of experimental Staphylococcus aureus prosthetic joint infections," European Journal of Nuclear Medicine and Molecular Imaging, vol. 34, no. 8, pp. 1302-1309, 2007.

[141] C. P. J. M. Brouwer, F. F. A. Y. Gemmel, and M. M. Welling, "Evaluation of ${ }^{99 m}$ Tc-UBI 29-41 scintigraphy for specific detection of experimental multidrug-resistant Staphylococcus aureus bacterial endocarditis," Quarterly Journal of Nuclear Medicine and Molecular Imaging, vol. 54, no. 4, pp. 442450, 2010.

[142] M. M. Welling, A. Lupetti, H. S. Balter et al., " ${ }^{~} 99 m$ Tc-labeled antimicrobial peptides for detection of bacterial and Candida albicans infections," Journal of Nuclear Medicine, vol. 42, no. 5, pp. 788-794, 2001.

[143] A. Lupetti, M. M. Welling, U. Mazzi, P. H. Nibbering, and E. K. Pauwels, "Technetium-99m labelled fluconazole and antimicrobial peptides for imaging of Candida albicans and 
Aspergillus fumigatus infections," European Journal of $\mathrm{Nu}$ clear Medicine, vol. 29, no. 5, pp. 674-679, 2002.

[144] P. H. Nibbering, M. M. Welling, A. Paulusma-Annema, C. P. J. M. Brouwer, A. Lupetti, and E. K. J. Pauwels, " ${ }^{99 m}$ Tclabeled UBI 29-41 peptide for monitoring the efficacy of antimicrobial agents in mice infected with staphylococcus aureus," Journal of Nuclear Medicine, vol. 45, pp. 321-326, 2004.

[145] L. Meléndez-Alafort, J. Rodríguez-Cortés, G. Ferro-Flores et al., "Biokinetics of ${ }^{99 m}$ Tc-UBI 29-41 in humans," Nuclear Medicine and Biology, vol. 31, no. 3, pp. 373-379, 2004.

[146] E. Vallejo, I. Martinz, A. Tejero, S. Hermandez et al., "Clinical utility of ${ }^{99 m}$ Tc-labeled ubiquicidin 29-41 antimicrobial peptide for sctigraphic detection of mediastinitis after cardiac surgery," Archives of Medical Research, vol. 39, no. 8, pp. 768$774,2008$.

[147] J. Supulveda-Mendez, C. A. de Murphy, J. C. Rojas-Bautista, and M. Pedraza-Lopez, "Specificity of 99m-Tc-UBI for detecting foci in patients with fever in study," Nuclear Medicine Communications, vol. 31, no. 10, pp. 889-895, 2010.

[148] C. Dillmann-Arroyo, R. Cantu-Leal, H. Camp-Nunez, C. Lopez-Carazosc et al., "Application of the ubiquicidin 29-41 scan in the diagnosis of pyogenic vertebral osteomyelitis," Acta Ortopédica Mexicana, vol. 25, no. 1, pp. 27-31, 2011.

[149] M. Assadi, K. Vahdat, I. Nabipour, M. R. Sehhat, F. Hadanvand et al., "Diagnostic value of ${ }^{99 m} \mathrm{Tc}$-ubiquicidin scintigraphy for osteomyelitis and comparison with ${ }^{99 m} \mathrm{Tc}$-methylene diphosphonate scintigraphy and magnetic resonance imaging," Nuclear Medicine Communications, vol. 32, no. 8, pp. 716-723, 2011.

[150] B. Nazari, Z. Azizmohammadi, M. Rajaei et al., "Role of ${ }^{99 m}$ Tc-ubiquicidin 29-41 scintigraphy to monitor antibiotic therapy in patients with orthopaedic infection: a preliminary study," Nuclear Medicine Communications, vol. 32, no. 8, pp. 745-751, 2011.

[151] R. E. Bishop, H. S. Gibbons, T. Guina, M. S. Trent, S. I. Miller, and C. R. H. Raetz, "Transfer of palmitate from phospholipids to lipid A in outer membranes of Gram-negative bacteria," EMBO Journal, vol. 19, no. 19, pp. 5071-5080, 2000.

[152] A. Peschel, R. W. Jack, M. Otto et al., "Staphylococcus aureus resistance to human defensins and evasion of neutrophil killing via the novel virulence factor MprF is based on modification of membrane lipids with L-lysine," Journal of Experimental Medicine, vol. 193, no. 9, pp. 1067-1076, 2001.

[153] A. Peschel, "How do bacteria resist human antimicrobial peptides?" Trends in Microbiology, vol. 10, no. 4, pp. 179-186, 2002.

[154] M. H. Limoncu, S. Ermertcan, C. B. Cetin, G. Cosar, and G. Dinc, "Emergence of phenotypic resistance to ciprofloxacin and levofloxacin in methicillin resistant and methicillinsensitive staphylococcus aureus strains," International Journal of Antimicrobial Agents, vol. 5, pp. 420-424, 2003. 

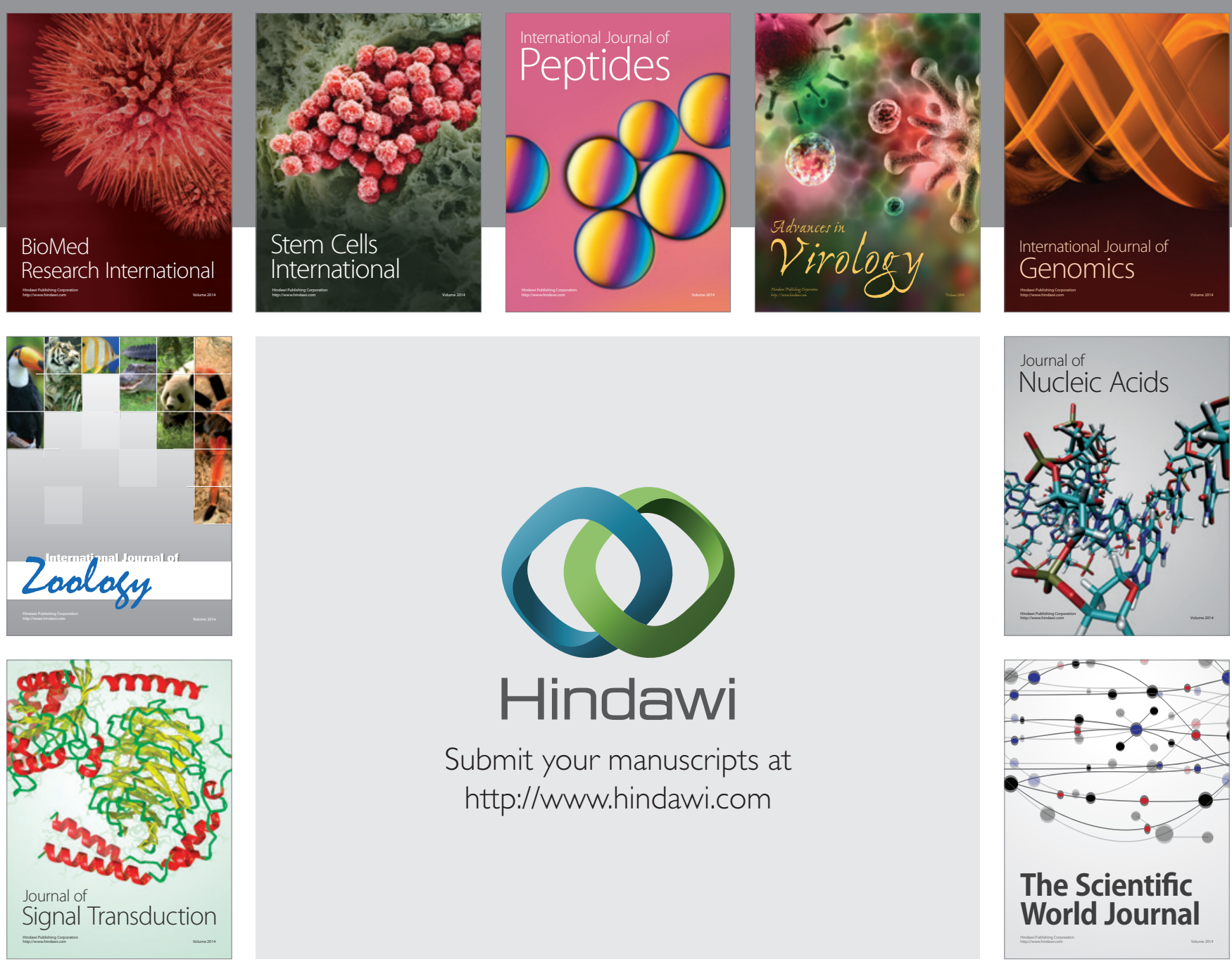

Submit your manuscripts at

http://www.hindawi.com
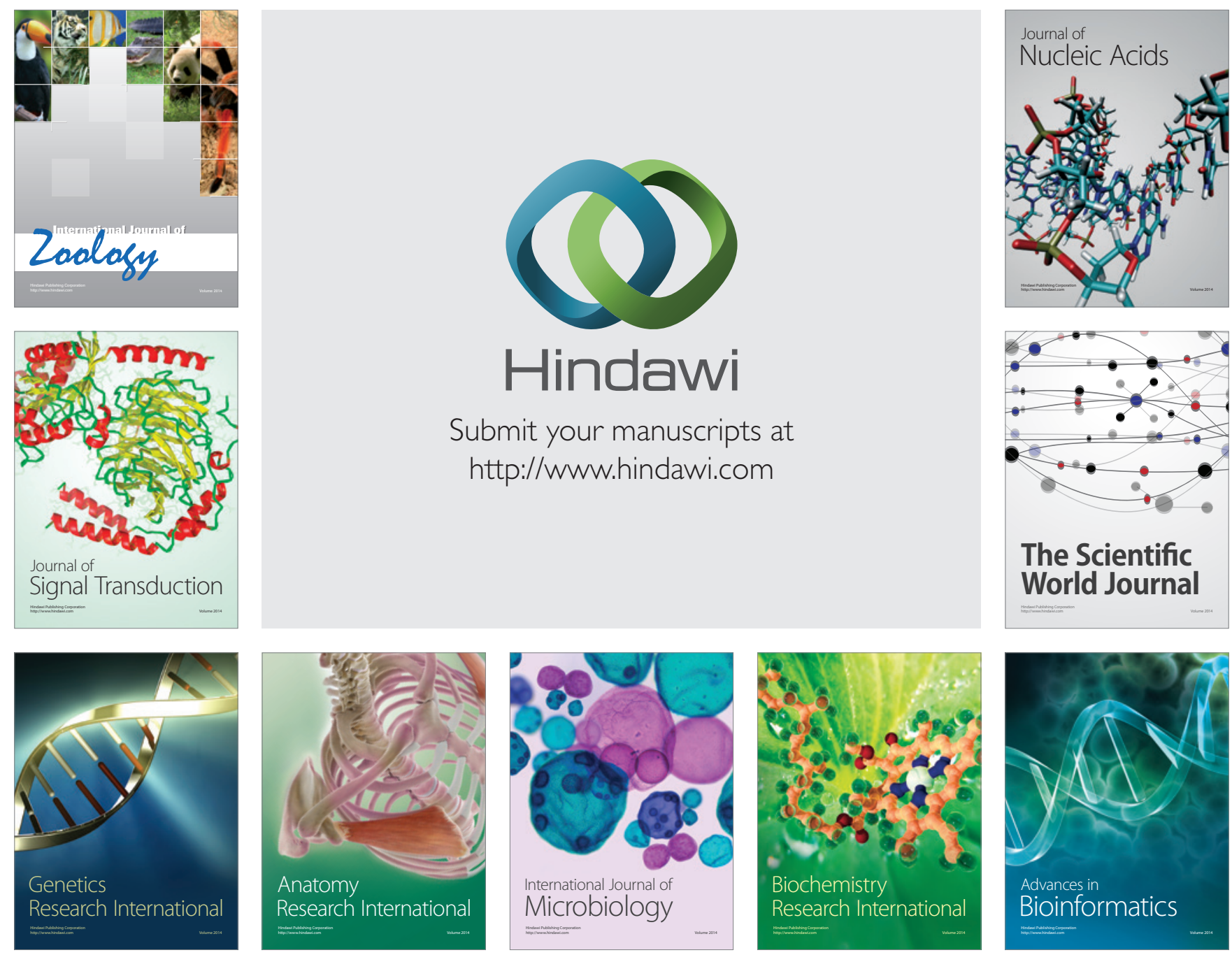

The Scientific World Journal
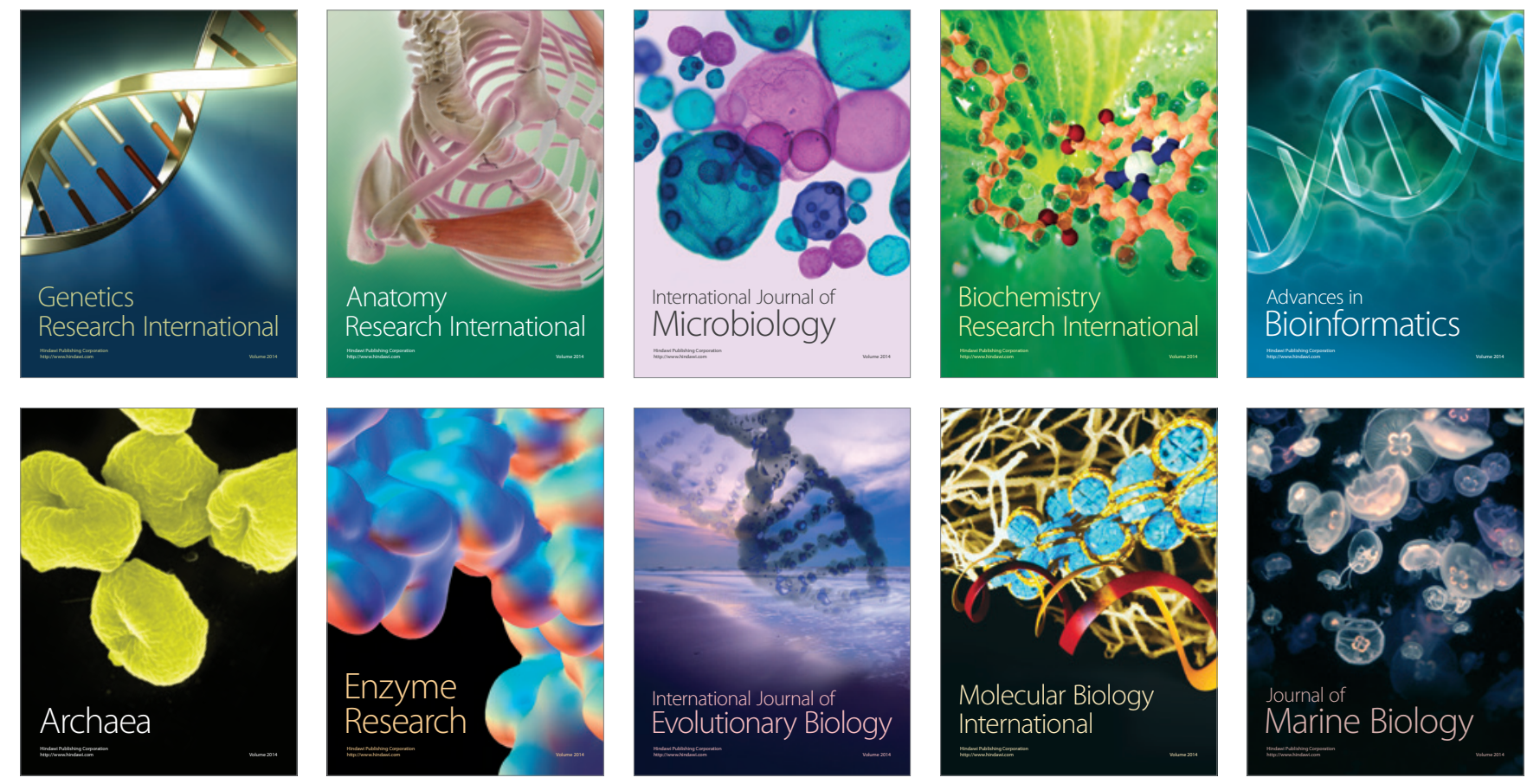